\title{
Tildelingsmodeller og effektbaserede principper i den offentlige sektor ${ }^{\mathrm{i}}$
}

\author{
Af Per Nikolaj Bukh og Karina Skovvang Christensen *)
}

\section{Resumé}

I de senere år er fokus øget både på den effekt, der opnås af de offentlige indsatser, og på de ressourcer, der medgår. Det nødvendiggør ændringer i den økonomiske styring, og i den måde ressourcetildelingsmodellerne fungerer på. Artiklen sætter fokus på ledelsesrummet, der drejer sig om, hvilke beslutninger man kan træffe, hvilke konsekvenser af beslutninger man har ansvar for, samt hvordan beslutningerne og konsekvenserne af dem påvirker de økonomiske rammer. Artiklens centrale pointe er, at tildelingsmodellerne konstruerer ledelsesrummet. Effektbaseret økonomistyring er derfor et spørgsmål om tildelingsmodeller (og dermed ledelsesrum), der sikrer helhedsorientering og sammenhængende styring af forløb. For at kunne vurdere tildelingsmodellernes egenskaber ser vi på omkostningseffektivitet som det centrale styringskriterie. I artiklen skelnes mellem direkte effektbaserede tildelingsmodeller, hvor tildelingskriterierne er formuleret som effektmål, og indirekte effektbaserede tildelingsmodeller, hvor tildelingskriterierne skal sikre økonomiske incitamenter til at øge omkostningseffektiviteten, men uden at effekt indgår som et tildelingskriterie. Vi skitserer grundprincipperne i en effektbaseret tildelingsmodel, idet vi dels viser, hvordan der indbygges direkte incitamenter i tildelingsmodellen, og dels diskuterer, hvilke betingelser der skal være opfyldt, for at direkte effektbaserede tildelingsmodeller kan anvendes. Pedersens nye anerkendelsespraksis, der adresseres i den anden artikel i dette nummer.

\section{Emneord}

Effekt, forløbsstyring, ledelsesrum, lighed, omkostningseffektivitet, tildelingsmodeller, økonomistyring

*) Per Nikolaj Bukh er cand.oecon. og ph.d. samt professor i økonomistyring ved Aalborg Universitet. Karina Skovvang Christensen er cand.oecon. og ph.d. samt lektor ved Institut for Økonomi, Aarhus Universitet. 


\section{A. Indledning}

\section{Artiklens baggrund}

Effekt er gennem de senere år blevet et centralt omdrejningspunkt for mange af de faglige såvel som ledelsesmæssige ændringstiltag i den offentlige sektor. Det kan der være mange årsager til, men det øgede faglige fokus på effekt skyldes ikke mindst de begrænsede budgetter, som har gjort det nødvendigt at undersøge, hvorvidt opgaver kan løses med bedre resultater uden at øge udgifterne. Selvom det økonomiske pres opleves markant i de fleste dele af den offentlige sektor, har styringsudfordringerne været særligt markante på socialområdet, hvor budgetoverskridelser er både hyppige og store. I forlængelse af opbremsningen i den kommunale udgiftsvækst fra 2010 er økonomistyring og omkostningsbevidsthed derfor kommet i fokus (Bukh \& Svanholt 2019, 2020; Bukh et al. 2020), og vi har argumenteret for, at økonomistyringen skal være effektbaseret (Bukh \& Christensen 2018b, 2018c, 2019, 2020; Christensen \& Bukh 2018).

Det centrale i den form for effektbaserede strategier og styring, som træder frem i disse år, er ikke så meget, at der er fokus på effekt, men at der samtidig også er fokus på den økonomiske side af aktiviteten, og at effektstyring dermed også er et spørgsmål om økonomistyring. Fra tidligere at have et primært fokus på budgetoverholdelse og udgiftskontrol orienteres økonomistyringsmodeller i disse år mod at sikre omkostningseffektivitet, fremme de offentlige virksomheders målsætninger og skabe værdi for den enkelte borger såvel som for samfundet i sin helhed.

Effektbaseret strategi og styring er et taknemmeligt begreb, fordi det intuitivt er rigtigt at koncentrere sig om de indsatser, der har mest effekt, og i særdeleshed fjerne dem, der ikke skaber effekt eller ligefrem har negativ effekt. Ligeså intuitivt rigtigt er det, at strategier og styring i den offentlige sektor også skal handle om, hvilken effekt der ønskes opnået. Men det er også et kompliceret begreb, fordi der er mange typer effekt, og fordi effekt ikke et neutralt begreb. Det afspejler bestemte værdier og mål. Derfor kræves prioriteringer mellem værdier og mål, ligesom der i en offentlig virksomhed altid vil være hensyn til forskellige mål og interessenter, der i et eller andet omfang løbende skal vægtes, når der tages beslutninger.

Kompleksiteten og afvejningen af potentielt modstridende målsætninger komplicerer også udviklingen af den økonomiske styring. Dette skyldes ikke kun, at budgetforudsætninger og de kriterier, som ressourcefordelingen skal baseres på, er komplekse og flertydige, men også at interessenterne ofte er uenige om, hvilke målsætninger der er relevante, og hvordan målsætningerne skal afvejes. Dermed bliver økonomistyringen, som beskrevet af Melander (1994) en kamparena, hvor økonomistyringens økonomiske logik kan stå i modsætning til "andre rationaler og værdier i organisationen" (ibid., p. 152), og hvor økonomistyringen ikke blot skaber nye sproglige 
udtryksformer, men også griber ind i aktørernes adfærd og konstruerer nye virkelighedsbilleder og handlingsnormer.

I den offentlige sektor har et effektbaseret perspektiv i princippet potentialet til at revitalisere styringen, men et krav om fokus på effekt kan også blive udfordret netop af det øgede behov for at prioritere. Allerede for næsten 50 år siden påpegede Steven Kerr, at politiske målsætninger ofte er

...purposely vague and general and do not indicate... the host of decisions that must be made among alternative ways of achieving official goals and the priority of multiple goals ... [t]hey usually may be relied on to offend absolutely no one, and in this sense can be considered high acceptance, low quality goals (Kerr 1975, p. 769).

Det er et paradoks, der stadig er relevant, da den offentlige sektors målsætninger grundlæggende er politisk bestemte. Paradokset bliver endnu mere markant af, at politikere samtidig udtrykker målsætninger om at prioritere ved få mål; for eksempel at folketinget "vedtager 2-3 nationale mål for folkeskolerne, daginstitutionerne, ældreplejen og de andre velfærdsområder" (Socialdemokratiet 2018, p. 12).

Hvis den offentlige sektor skal fokusere på få overordnede målsætninger, er det afgørende, at disse på den ene side kan rumme bredden af aktiviteter på de enkelte velfærdsområder, og på den anden side er relevante og passende ambitiøse. Transformationen fra de få overordnede målsætninger til konkrete mål kan, som Mouritsen (2018, p. 231-232) påpeger, føre til en trivialisering eller forskydning af formålet, fordi sammenhængen mellem formål og mål er ukomplet. Det skaber, som Mouritsen (2018) også fremhæver, et dilemma, der fordrer at blive håndteret. Det er der ikke en nem løsning på, men et bud er, at de mål, der formuleres, skal være for effekt - herunder, at de skal være helhedsorienterede fremfor eksempelvis at vedrøre enkeltaktiviteter. For at sådanne mål får gennemslagskraft, er det afgørende, at de prioriteres, og at de bliver centrale i styringsmodellerne. Det gælder både for den offentlige sektor i sin helhed og i de enkelte offentlige virksomheder.

\section{Tildelingsmodellens rolle}

Store dele af den offentlige sektors aktiviteter er stedsspecifikke forstået på den måde, at de enten vedrører specifikke geografiske områder, som for eksempel kommuner og regioner, eller specifikke decentrale institutioner, som for eksempel skoler, universiteter og hospitaler. Sådanne enheder kunne i princippet være fuldt finansieret af de borgere eller andre, som de servicerer, via direkte skatter og/eller brugerbetalinger. I Danmark er den mest udbredte praksis dog, at de fleste offentlige aktiviteter direkte eller indirekte er finasieret helt eller delvist af staten. 
Når vi ser bort fra enkelte detaljer, er de offentlige sygehuse eksempelvis fuldt finansieret af regionerne, der igen er finansieret ca. $80 \%$ af staten og ca. $20 \%$ af kommunerne ved den kommunale medfinansiering. Kommunerne er delvist finansieret af kommuneskatten og delvist af bloktilskud fra staten, samtidig med at den såkaldte udligningsmodel omfordeler ressourcer kommunerne imellem. Tilsvarende modtager folkeskoler deres finansiering fra kommunerne, mens børnehaver udover den kommunale finansiering er delvist brugerbetalte.

Der findes en omfattende litteratur om fiskal føderalisme, der bl.a. modellerer, hvordan bevillinger fra centrale til lokale myndigheder kan tilrettelægges (f.eks. Oates 1999), og mange af disse principper kan anvendes, som påpeget af både Smith (2007, p. 2) og Heeager et al. (2019, p. 213), når tildelingsmodeller allokerer ressourcer til decentrale enheder. Sådanne modeller har det fællestræk, at de konstruerer en vertikal, dvs. hierarkisk, relation mellem et overliggende styringsniveau, der opfattes som en betaler, og et underliggende styringsniveau i form af en udførerenhed ('service provider').

I sin ideelle form baseres tildelingsmodellen på, at betaleren på forhånd specificerer betalingskriterierne ved en matematisk formel, således at denne formel bestemmer ressourceallokeringen til udførerenheden for en given periode; samt at der i løbet af budgetperioden ikke foretages ændringer i formlen. For at dette princip kan fungere i sin rene form skal fire institutionelle betingelser være opfyldt (jf. Smith 2007, afsnit 1.4):

1. Det skal i et vist omfang være muligt at delegere beslutningskompetence til udføreren.

2. Betalerens målsætninger skal kunne operationaliseres til egnede mål, der afspejler den opgave, udføreren forventes at løse.

3. Betalingsformlen skal kunne specificeres ex ante, og der skal være egnede, verificerbare og rettidige data til rådighed, så formlen kan anvendes ex post til at allokere ressourcer.

4. Betalingsformlen skal indebære tilstrækkelige incitamenter til, at udføreren præsterer i overensstemmelse med betalerens præferencer udtrykt ved betalingsformlen.

Tildelingsmodeller er den centrale komponent i budgetmodellerne i store dele af den offentlige sektor, idet de udgør grundlaget for ressourcetildelingen til de selvejende uddannelsesinstitutioner (taxametermodeller), hospitaler (DRG-modeller), socialområdet (takstbekendtgørelsen), folkeskoleområdet (skoletildelingsmodeller), arbejdsmarkedsområdet (refusionsmodeller) samt ældreområdet (BUM-modellen). Herudover er hele udligningssystemet og det statslige bloktilskud til kommuner og regioner tildelingsmodeller. 


\section{Tildelingsmodellens rolle}

I praksis består økonomistyring af en mængde teknikker og metoder, der bringes i anvendelse for at løse en række ledelsesopgaver i en specifik virksomhed; og tildelingsmodellen indgår som en af disse komponenter. Virksomheden kan ofte selv bestemme graden af økonomistyring i forhold til at løse disse opgaver. Eksempelvis vil der altid være brug for at planlægge og koordinere (hvilket kan gøres ved anvendelse af økonomistyringen), men det er et ledelsesmæssigt valg, i hvilket omfang man planlægger og koordinerer, ligesom både planlægning og koordinering kan gøres på mange forskellige måder - også uden anvendelse af økonomistyring. Økonomistyring er derfor ikke et system, der eksisterer uafhængigt af den enkelte virksomhed, og økonomistyringen skal passe til virksomhedens mål og strategier, dens organisering samt den måde, virksomheden ledes på. Det har den naturlige konsekvens, at ændringer i virksomhedens mål og strategier vil have betydning for, hvordan virksomheden skal ledes og dermed også for, hvordan økonomistyringen skal indrettes.

Da økonomistyringen har stor indflydelse på ledelsesmulighederne, er det en væsentlig ledelsesopgave at beslutte, hvilke egenskaber økonomistyringen skal have. Det kræver imidlertid et vist kendskab til økonomistyring at kunne indgå i en dialog om udvikling af økonomisk styring. Man skal have viden om økonomistyringens muligheder, og om hvorledes modeller og teknikker har forskellige roller i den samlede økonomistyringsmodel (Bukh 2008, 2009) for, at man kan indtage rollen som den kvalificerede bestiller af en egnet økonomistyringsmodel. Den enkelte virksomhed har stor frihed til selv at designe sin økonomistyring, hvilket netop er det, der adskiller økonomistyring fra det eksterne regnskabs opgaver.

Vores udgangspunkt er, at økonomistyringsmodeller, dvs. de værktøjer og teknikker, som man tager i brug, ikke er færdige løsninger, som man installerer modul for modul. Modellerne har derimod karakter af opskrifter (jf. Røvik 2007) på, hvordan idéer, der nogle gange fremstår abstrakte, kan oversættes til praksis i en konkret virksomhed. Det kan f.eks. være princippet om, at de mål, vi styrer efter, samtidig skal være kritiske for strategiens realisering og relevante for medarbejdernes daglige arbejde, eller at princippet for bevillingen til en afdeling skal være afhængig af den effekt, der opnås. Denne oversættelse eller kontekstualisering (Røvik 2007, kapitel 13) indebærer bevidste ledelsesmæssige valg, og vi taler derfor om, at økonomistyringen skal designes til brugen i den enkelte virksomhed.

Økonomistyringsmodellerne er ikke færdige moduler, men vejledninger i, hvordan man f.eks. klassificerer data, udfører beregninger, strukturerer information og træffer beslutninger på baggrund af data. Modellerne er også anvisninger på, hvilke faktorer der forventes at have en betydning i implementeringen, hvilke faser man skal igennem, hvilke konsekvenser de valg, man 
træffer under indførelsen, vil have for den måde, medarbejdere og ledere vil reagere og agere, og hvordan resultater i forhold til f.eks. effektivisering og effektskabelse skal opnås.

Dette perspektiv betyder for det første, at en økonomistyringsmodel ikke har en færdig idealtilstand, så man på forhånd kan slå op i en bog og se, hvordan en økonomistyringsmodel bør se ud, eller hvilke egenskaber den vil have. For det andet betyder det, at 'tilpasninger' af økonomistyringsmodeller til den konkrete virksomheds økonomstyringspraksis ikke nødvendigvis er et udtryk for, at man kun anvender modellerne delvist, da de ofte netop indeholder anvisningerne på, hvordan økonomistyringen bør tilpasses. For det tredje betyder det, at tilpasningen af modellen skal ske under hensyntagen til den konkrete virksomheds situation, herunder de opgaver som økonomistyringen skal løse. Endelig betyder det for det fjerde, at tilpasningen også er en tilpasning af ledelsesprincipperne og de andre økonomistyringsmodeller, som anvendes i virksomheden (Christensen \& Bukh 2018).

For at kunne navigere i mængden af mulige teknikker og forbedringstiltag er det nødvendigt at have en så præcis som mulig indsigt $\mathrm{i}$, hvorledes de teknikker og metoder, der eventuelt kunne forbedre økonomistyring, virker. Her er det ikke tilstrækkeligt at forstå de overordnede principper, da disse på det overordnede plan næsten altid lyder tilforladelige. Det er de konkrete designvalg, inden for de enkelte metoder, der afgør om disse metoder fungerer i den konkrete virksomhed eller ej - og det kræver både praktisk erfaring med teknikkerne og teoretisk indsigt i, hvordan de virker (Bukh 2005)

Ved bedre at forstå teknikkerne bag konstruktionen af sådanne modeller kan fordele og ulemper ved forskellige modeller identificeres og analyseres. Dermed kan en bedre forståelse for tildelingsmodeller betyde en forbedret økonomistyring på centrale velfærdsområder og således en bedre og mere velfungerende offentlig sektor. Det kan fjerne nogle, men naturligvis ikke alle, problemer forbundet med den økonomiske styring. Derfor kan en bedre forståelse for tildelingsmodellers principper bidrage til en bedre og mere velfungerende offentlig sektor.

\section{Fokus på effekt}

Produktivitetskommissionen (2013) pointerede, at der på alle områder i den offentlige sektor burde formuleres klare politiske krav om høj produktivitet og effektivitet, samtidig med at ledere og medarbejdere burde have flere frihedsgrader i opgaveløsningen. Det blev også anbefalet, at lederne, via økonomistyringen, fik mere fokus på kerneopgaven og den overordnede strategi, samt at principperne for ramme- og takststyring blev justeret på en række områder, herunder især uddannelses- og sundhedsområdet. Dette er essensen af, hvad effektbaseret strategi og styring drejer sig om, nemlig: Sæt relevante mål for, hvilke resultater der skal opnås i relation til kerneopgaven; udvid ledelsesrummet, så ledere og medarbejdere kan fastlægge og gennemføre 
aktiviteterne under ansvar for resultaterne; og indret den økonomiske styring og ressourcetildelingsmodellerne, så frihedsgraderne øges og resultatskabelsen fremmes.

Den offentlige sektor har i princippet altid haft som formål at skabe effekt, men det var ikke før i midten af 00'erne, at effekt begyndte at få et særskilt ledelsesmæssigt fokus i Danmark. Det var særligt flere kommuners arbejde med den såkaldte resultatbaserede styring (Nielsen et al. 2005; Ejler et al. 2008; Moss-Bjerre et al. 2010), hvor man især fokuserede på evidensbaserede indsatser, evalueringsmetoder og anvendelse af forandringsteorier, der markerede en faglig ændring ${ }^{\text {ii }}$ I kølvandet på finanskrisen og den kraftige opbremsning af den kommunale økonomi i 2010 begyndte enkelte kommuner at have et mere styringsmæssigt og strategisk fokus på effekt, som drejede sig mindre om evalueringer, målesystemer og forandringsteorier og mere om den strategiske ændring af velfærdssamfundet.

To til tre år efter finanskrisen kom der så småt mere fokus på at få integreret den effektbaserede styring i de administrative og politiske ledelsesprocesser (f.eks. Gaarde \& Lønbæk 2018) og ikke mindst i ressourcetildelingsmodellerne (Christensen \& Bukh 2018; Holmgaard 2014, kapitel 7; Jensen \& Olesen 2018a, 2018b). Regionerne har ligeledes erkendt, at der er brug for nye styringsmodeller og har fra 2015 gennemført en række pilotprojekter og initiativeriii, der delvist er inspireret af Value-Based Health Care ${ }^{\text {iv }}$ (Porter \& Lee 2013; Porter \& Teisberg 2006). Dermed er der også på sundhedsområdet fokus på at sætte en ny dagsorden, hvor justeringer af den økonomiske styring er en væsentlig faktor (Danske Regioner 2016).

\section{Artiklens formål og opbygning}

I denne artikel sætter vi fokus på økonomistyringens rolle i relation til ledelsesrummet (Bukh \& Christensen 2018a) og adresserer, hvordan en effektbaseret tildelingsmodel kan udformes med udgangspunkt i, at den offentlige sektor skal være omkostningseffektiv.

Artiklen har tre formål. For det første vil vi vise, hvordan et ledelsesrum kan fastlægges ved anvendelse af tildelingsmodeller, samt hvordan forskellige målsætninger har betydning for, hvordan tildelingsmodellerne skal indrettes. For det andet vil vi introducere de overordnede principper for effektbaseret økonomistyring og diskutere, hvilken betydning et effektfokus har for tildelingsmodellerne. Endelig vil vi præsentere en generel model for, hvordan tildelingsmodeller kan forstås, analyseres og udvikles.

Den resterende del af artiklen er struktureret således, at vi i afsnit B introducere ledelsesrummets tre dimensioner, idet vi især vil lægge vægt på betydningen af det økonomiske ansvar. I afsnit C ser vi på, hvad en tildelingsmodel er, samt hvordan den udvikles med udgangspunkt i udgiftsbehov og risikojustering. Med dette udgangspunkt sætter vi i afsnit D fokus på omkostningseffektivitet som 
det centrale kriterie for økonomistyring, hvorefter vi i afsnit E diskuterer, hvordan hensynet til horisontal og vertikal lighed indgår i en tildelingsmodel. I afsnit F går vi mere i detaljer med, hvad direkte effektbaseret økonomistyring er. Endelig afsluttes artiklen i afsnit G.

\section{B. Ledelsesrummet}

Uanset hvilken vision vi har for samfundets udvikling, er der brug for værktøjer til at kunne påvirke udviklingen. God ledelse og styring skal være med til at skabe både råderum og ledelsesrum, og parallelt med ændringer i den offentlige sektors målsætninger er der brug for at ændre rammerne for opgaveløsning på det decentrale niveau ved hjælp af økonomistyringen. Der er brug for at fokusere mere på at udvikle en økonomisk styring, der centrerer sig om resultaterne af aktiviteterne og de omkostninger, der er forbundet med at skabe resultaterne, fremfor at være orienteret mod overholdelse af regnskabsregler og budgetter, kontrol af bevillinger, rammestyring og dokumentation af forbrug.

\section{Hvad er et ledelsesrum?}

Nye prioriteringer og nye mål fordrer ændringer langt ned i organisationen i de offentlige virksomheder. Hvis ikke vi skal opnå det samme, skal vi heller ikke gøre det samme. Derfor skal ledere og medarbejdere have mulighederne for gøre noget andet, hvilket først og fremmest betyder, at ledelsesrummet skal ændres. Kort sagt handler ledelsesrummet om "de handlemuligheder, en leder har i jobbet" (Væksthus for Ledelse 2009, p. 4) eller med andre ord: lederens mulighed for at udøve ledelse.

Ledelsesrummet handler imidlertid også om, hvad man har ansvar for, og hvordan den ledelse, man udøver, og de resultater, man opnår, hænger sammen med de ressourcer, man har til rådighed. Ledelsesrummet fastlægges i samspillet mellem en række faktorer, hvor ikke mindst organisationsstrukturen, og det ledelsesansvar som denne indebærer, er afgørende, Men ledelsesrummet formes også af den økonomiske styring, hvor ansvarscenterstrukturen ('responsibility accounting') med den konstruktion af afdelinger og budgetansvar som omkostnings, omsætnings-, profit- og investeringscentre og tilknyttede variansanalyse (Anthony \& Govindarajan 2006) bestemmer, hvilket økonomisk ansvar en leder har.

Når en organisatorisk enhed tildeles ressourcer ved en tildelingsmodel, konstrueres en omsætningsdimension, således at lederen ikke alene har ansvar for de udgifter der afholdes, men også for organisationens indtægter. Selvom enheden ikke har som opgave at skabe indtjening, men ofte blot at overholde budgettet (som konstrueres ved tildelingsmodellen) fungerer en sådan enhed dermed som et profitcenter, hvor indtjeningsmålsætningen er at nulresultat. 
Når vi taler om ledelsesrummet, gør vi det derfor ud fra tre dimensioner (jf. Bukh \& Christensen 2018a, 2018b), hvor de afgørende spørgsmål er:

1. Hvilke beslutninger kan man træffe, og hvilke aktiviteter kan man gennemføre?

2. Hvilke konsekvenser af beslutninger og aktiviteter har man ansvar for?

3. Hvordan påvirker beslutningerne og konsekvenserne de økonomiske rammer?

For at man kan fungere effektivt som leder, skal dimensionerne være afstemt med hinanden og passe til den opgave, man har ansvar for. Spørgsmålet er altså ikke blot, hvilke beslutninger man kan træffe, men også hvilket ansvar man har for de resultater, der opnås. Derfor handler ledelsesrummet i høj grad også om budgetter, økonomisk ansvar og de muligheder, man har for at agere i dette rum.

Ansvar er en central dimension af ledelsesrummet, men det er sjældent en stabil størrelse. Det kan ændres over tid, og det kan pludselig vise sig at være anderledes, end man troede. Desuden kan lederes proaktive handlinger (eller mangel på samme) øge eller reducere ledelsesrummet. Vi hører ofte ledere bede om større ledelsesrum i form af flere handlemuligheder, men for de fleste er det klare grænser for ledelsesrummet, de efterspørger, idet gråzoner sår tvivl om både ledelsesretten og ansvaret. Det gælder både faglige og økonomiske gråzoner.

Den tredje dimension ovenfor angiver netop, at ledelsesrum også er et spørgsmål om, hvordan man definerer det faglige og økonomiske ansvar. Ledere bliver nødt til også at interessere sig for økonomiske styringsmodeller, fordi styring af økonomien spiller en lige så stor rolle som den formelle organisering, når ledelsesrummet defineres. Beslutningsautonomi og -ansvar skal passe sammen. Det nytter ikke at få ansvar for en opgave, hvis ikke man har de frihedsgrader, der er nødvendige for at løse den effektivt. Men det fungerer heller ikke, hvis det budget, man får tildelt, og de principper, det er tildelt efter, ikke passer til den måde, opgaven forventes at blive løst på, og det ansvar man har.

Når ressourcetildelingen funderes på en tildelingsmodel, strukturerer den i sammenhæng med regler og øvrige rammer adfærden, således at lederen har frihedsgrader, men ikke fuld frihed, til at løse opgaverne. Selvom tildelingsmodellen og det økonomiske ansvar giver nogenlunde faste rammer, betyder det ikke med sikkerhed, at de ønskede resultater opnås, eller at budgettet med sikkerhed overholdes, men det økonomiske ansvar indebærer incitamenter til at opnå de mål, der tildeles ressourcer efter samt incitamenter til ikke at overskride budgettet. Dermed skabes markedsmekanismer i forventningen om, at de "skaber højere effektivitet end kommandoøkonomi" (Melander 1994, p. 154), fordi incitamenterne til prioritering er stærkere ved en markedsøkonomi. 


\section{Ledelsesrummet kan ændres: kommuner og regioner}

Ledelsesrummet kan ændres ved at ændre målene for, hvad der skal opnås, og vilkårene for, hvordan det skal opnås. Ligeledes udvides ledelsesrummet, når den økonomiske styring rettes mod forløb fremfor aktiviteter, eller når større dele af budgettet eksempelvis udmøntes til distrikter fremfor til specifikke indsatser; i begge tilfælde ved anvendelse af tildelingsmodeller baseret på eksplicitte finansieringsformler (Mayston 1998; Smith 2007), der bestemmer, hvilke budgetter der tildeles de decentrale enheder, hvad enten det er skoler, hospitaler, botilbud, jobcentre eller andre enheder.

Ganske vist har statens økonomiske styring via økonomiaftaler og budgetlov - og ikke mindst de regnskabs- og budgetsanktioner, der er indbygget heri - reduceret kommunernes frihedsgrader, når den økonomiske styring skal tilrettelægges i den enkelte kommune. Men reelt set har kommunerne vidtstrakte muligheder for at sætte egne mål og organisere sig, som man ønsker, samt beslutte, hvordan den kommunale service skal leveres. Lovgivningen på de enkelte fagområder, heriblandt folkeskoleloven og serviceloven, giver dog nogle begrænsninger. Det gælder eksempelvis, hvad angår anvendelsen af effektafhængige betalinger for de tilbud, der er omfattet af takstbekendtgørelsen på de sociale områder. Samlet set er der imidlertid langt flere muligheder for at forbedre styringen, end der er begrænsninger. Derfor er der mange muligheder for at udvikle en bedre økonomistyring.

Regionerne er i en anden situation i forhold til sundhedsvæsnet. På den ene side fremstår regionsrådets ledelsesrum klart og veldefineret: Opgaven består i at varetage sygehusvæsnets opgaver og yde sygehusbehandling til regionens borgerne; at forbedre sundheden ud fra de nationale mål (Sundheds- og Aldreministeriet 2016); at sikre den produktivitet, som økonomiaftalen mere eller mindre eksplicit forudsætter; samt at opfylde patientrettigheder vedr. udredning og behandling til punkt og prikke. Da regionerne ikke har mulighed for at påvirke indtægterne ved skatteudskrivning, kan de ikke lånefinansiere driften, og da de i princippet ikke har nogen kassebeholdning, som det kendes i kommunerne (likviditet efter kassekreditreglen), er budskabet også her ganske enkelt: Budgettet skal holdes. Det gælder både i kroner og i aktivitetsniveau, selvom aktiviteten og resultaterne i sundhedsvæsnet ikke længere nødvendigvis baseres på en måling af den producerede DRG-værdiv.

På den anden side er ledelsesrummet også uklart og kompliceret, og antallet af styringselementer er stort. I en analyse af de centrale elementer i den samlede statslige styring af det regionale sundhedsområde identificerer Højgaard et al. (2018) mere end en halv snes styringsinstrumenter ${ }^{\mathrm{vi}}$, og det anføres endda, at disse kun er et udpluk, og at analysen kun har fokus på styringen fra stat til region. Højgaard et al (2018, p. 19) konstaterer også, at ingen af disse styringsinstrumenter er perfekte, og at de sågar kan være i direkte konflikt. 


\section{Ledelsesrummenes koblinger og (u)fuldstændigheder}

Der har siden 1990'erne været stor forskningsmæssig interesse for, hvordan strategier - og dermed prioriteringer og forskellige målsætninger - bestemmer behovet for både økonomistyringskomponenter, relationerne mellem dem og anvendelsen af dem. Sådanne strategier og målsætninger forestilles oftest at være udviklet af topledelsen, defineret som "those responsible for ensuring that strategies are formulated and implemented" (Simons, 1990). Selvom topledelsen har autoritet til at beslutte strategierne og bestemme det overordnede økonomistyringsdesign, er decentrale styringselementer og vertikale koblinger, dvs. koblinger mellem hierarkiske niveauer, vigtige for, hvordan strategier implementeres og målsætninger realiseres (Bukh \& Svanholt 2020; Frow et al., 2010; Deschamps, 2019).

Der argumenteres i økonomistyringslitteraturen for, at den økonomiske styring skal analyseres som en samlet pakke eller et system (Bedford et al. 2016; Van der Kolk 2019; Malmi \& Brown 2008; Simons 1995) fremfor at se på de enkelte elementer isoleret set. Hovedparten af litteraturen ser imidlertid kun på de horisontale koblinger mellem elementerne, dvs. koblinger mellem styringselementer på samme hierarkiske nivieau eller koblinger mellem den intenderede og faktiske anvendelse af styringselementer. ${ }^{\text {vii }}$ I denne artikel interesserer vi os for den hierarkiske kobling mellem det overliggende styringsniveau (betaleren) og de underliggende styringsniveauer i form af udførerenheder ('service provider') samt for, hvordan denne kobling konstrueres gennem tildelingsmodellen.

Ledelsesrummets tre dimensioner afspejler tre forskellige facetter af de krav, der stilles til decentrale institutioner, og de muligheder en leder for disse har for at løse opgaverne. I den første dimension øges udførerenhedens beslutningskompetencer i takt med, at beslutningskompetencer uddelegeres (jf. Mouritsen 2018). Den anden dimension specificerer, hvordan betaleres målsætninger operationaliseres til mål, som udføreren har ansvar for. Endelig indebærer den tredje dimension en kalkulation i form af den tildelingsmodel, der beregner de økonomiske konsekvenser af beslutninger i et regnskabsresultat for udførerenheden. Dermed samler kalkulationen elementer, der ellers ville være adskilte, og der konstrueres et nyt objekt (Mouritsen 2016, p. 229).

I sin ideelle form ville tildelingsmodellen konstruere en fuldstændig oversættelse af betalerens målsætninger. Men, som Mouritsen skriver, er "sammenhængen mellem formål og mål ukomplet" (Mouritsen 2018, p. 232). Derfor vil enhver tildelingsmodel indebære incitamenter til at forfølge mål, som ikke er i overensstemmelse med betalerens målsætninger. Det kan betyde, at udføreren ud fra betalingsformlens iboende rationalitet træffer beslutninger og gennemfører handlinger, der ikke var forventet af betaleren. Dermed kan der opstå resultater, der ikke er i overensstemmelse med betalerens målsætninger, fordi de ikke er indeholdt i tildelingsmodellens framing. Sådanne 
handlinger repræsenterer overflows, der indebærer negative eksternaliteter, hvis de har uønskede konsekvenser for betaleren, som udføreren ikke tager i betragtning (Callon 1998, p. 248). Der kan imidlertid også være tale om positive eksternaliteter, som Poulsen et al. (2020) viser i et studie af den såkaldte Pulje til Elevløft.

Graden af den hierarkiske kobling påvirkes af incitamenternes styrke, men da tildelingsmodeller i deres natur vil indebære en ufuldstændig oversættelse af formål til mål, vil en løsere kobling (Hengel et al. 2014) mellem mål og budgettildeling måske være at foretrække for betaleren, hvis udføreren i forvejen er motiveret til at forfølge betalerens målsætninger. Anvendelsen af tildelingsmodeller indebærer derfor, at det centrale behov for styring gennem mål skal afbalanceres med opnåelsen af formålet gennem decentrale frihedsgrader (Lewis et al. 2019).

\section{Tildelingsmodellen}

I økonomistyringen kan der skelnes mellem kalkulations-, styrings- og omkostningsmodeller (Bukh 2008, 2009). Et effektbaseret fokus får betydning for de principper, hvorefter disse modeller skal udvikles og anvendes (Bukh \& Christensen 2018b, afsnit III.3). Den væsentligste komponent blandt styringsmodellerne i kommuner og regioner er tildelingen af økonomiske ressourcer til de decentrale enheder, dvs. til skoler, dagtilbud, hospitalsafdelinger, sociale tilbud etc., ved anvendelse af tildelingsmodeller.

\section{Tildelingsmodellens principper}

Teknisk set er en tildelingsmodel en såkaldt formelbaseret finansiering ('formula funding'), jf. Smith (2007), hvor der gives en modelbestemt tildeling til en budgetenhed ud fra en ex ante fastlagt finansieringsformel i stedet for f.eks. en skønsmæssig ${ }^{\text {viii }}$ tildeling. I praksis må det dog ofte erkendes, at der kan være behov for at foretage specifikke tildelinger efter kriterier, der ikke er en del af modellen, eller for at kompensere for enkelte forhold, der ikke fuldt ud afspejles i modellen.

Overordet set består en tildelingsmodel, der tildeler finansielle ressourcer til decentrale "enheder" i form af afdelinger, virksomheder eller distrikterix af tre komponenter:

1. En fast tildeling til enheden, hvilket er udtryk for en beslutning om f.eks. at give en grundfinansiering til ledelse, nattevagt, husleje, administration etc.

2. En taksttildeling efter objektive kriterier med tilknyttede takster ('case funding'), f.eks. en tildeling pr. måned, pr. indsats eller pr. barn

3. En kapitatildeling, der udgør et risikojusteret beløb ('capitation funding'), f.eks. til et antal borgere i et distrikt, der er omfattet af tildelingen. 
Risikojusteringen er en justering efter behovet i distrikterne (Smith 2007, p. 52), hvilket sædvanligvis udtrykkes ved et indeks, der er statistisk estimeret ${ }^{\mathrm{x}}$ og angiver det relative udgiftsbehov i forhold til et gennemsnitsniveau. Med dette udgangspunkt bestemmes tildelingen til den enhed, der tildeles til (f.eks. et skoledistrikt, et hospital, et hjemmeplejeteam eller et botilbud), som summen af de tre komponenter ovenfor. Eksempelvis vil tildelingen, $D_{i}$, til distrikt $i$ bestå af en fast tildeling $\left(F_{i}\right)$, en taksttildeling $\left(T_{i}\right)$ og en kapitatildeling $\left(K_{i}\right)$, således at $D_{i}$, fastlægges ud fra forskellige komponenter (parametre, data m.v.). Disse elementer kunne på folkeskoleområdet ${ }^{\mathrm{xi}}$ eksempelvis være følgende:

$i=$ distriktet

$F_{i}=$ den faste tildeling til distriktet, f.eks. samme tildeling til ledelse og administration

$T_{i}=$ taksttildelingen til distriktet, f.eks. tildeling til klassebaseret undervisning

$K_{i}=$ kapitatildelingen til distriktet, f.eks. en tildeling til inklusionsindsatser

$A_{i}=$ antal personer i distriktet, f.eks. antal børn i skoledistriktet

$R=$ gennemsnitlig tildeling pr. person i distrikterne, f.eks. et beløb til inklusionsindsatser

$\gamma_{i}=$ relative udgiftsbehov i distriktet; udtrykt ved et indeks hvor $100=$ gennemsnitsbehov

$k=$ takstkriterier, f.eks. antal klasser eller antal børn

$t_{k}=$ taksten for takstkriterie $k$, f.eks. takst pr. klasse eller takst pr. barn

$n_{k i}=$ antal takstenheder for kriterie $k$ i distrikt $i$, f.eks. antal klasser eller antal børn på skolen

Dermed kan tildelingen til de enkelte skoler eller skoledistrikter fastlægges ved følgende bevillingsformel:

$D_{i}=F_{i}+T_{i}+K_{i}=F_{i}+\sum t_{k} \times n_{k i}+\left(A_{i} \times R \times \gamma_{i}\right)$

I praksis kan formlen være mere kompliceret end angivet ovenfor, og der kan som to yderpunkter være tale om, at der tildeles et budget, der alene er baseret på en takstbaseret tildeling (case finansiering) eller alene på en kapitafinansiering. Som et eksempel herpå kan nævnes, at de selvejende ungdomsuddannelsesinstitutioner i overvejende grad tildeles undervisningsressourcer efter taxametermodellen, der er takstbaseret.

Ligeledes er de sociale tilbud, der er reguleret efter takstbekendtgørelsen, som udgangspunkt finansieret alene ved et takstbudget, men flere kommuner (se f.eks. Kristensen 2018) er begyndt at anvende en kombination af faste tildelinger og takstildelinger til botilbud. I forlængelse heraf blev det med økonomiaftalen for 2019 mellem KL og Regeringen aftalt at igangsætte en analyse af køb og salg af ydelser og indsatser på det specialiserede socialområde. Analysearbejdet er nu tilendebragt, og der er opnået enighed om at gennemføre en ændring af taksberegningsprincipperne:

Med henblik på at skabe større gennemsigtighed og sammenlignelighed i taksterne på tværs af tilbud vil det fremadrettet blive obligatorisk, at tilbuddenes takster opdeles i en basis- og servicetakst. Basistaksten skal omfatte de omkostningselementer, som ikke 
er direkte borgerrettede (fx administration, ejendomsudgifter mv.), mens servicetaksten skal omfatte de omkostningselementer, som er direkte borgerrettede (løn til plejepersonale mv.). (KL 2019)

\section{Udgiftsbehov og risikojustering}

Risikojusteringen har til formål at justere tildelingen for de forhold, der på statistisk signifikant vis dels forklarer det nuværende udgiftsniveau og dels forskelle i udgiftsniveauet mellem forskellige distrikter. Ved denne fremgangsmåde vil risikojusteringen afspejle gennemsnitsenhedens adfærd og omstændigheder. Selvom det kan synes som en retfærdig fremgangsmåde, sikrer det dog ikke i sig selv, at ressourcerne fordeles ud fra givne betalerpræferencer, idet en statistisk fastlagt risikojustering ofte vil reproducere det bestående serviceniveau og den nuværende praksis.

\section{Tekstboks 1: Det sociale taxameter for ungdomsuddannelserne}

Taxametersystemet, der tildeler ressourcer til ungdomsuddannelserne, er primært baseret på antal årselever og tager derfor som udgangspunkt ikke hensyn til, at institutioner med mange elever med en svag social baggrund og et højt frafald kan have behov for flere ressourcer til at iværksætte en målrettet indsats for at reducere frafaldet. Det kan f.eks. være via en styrket undervisningsdifferentiering, mentorordninger eller lignende, der systematisk retter sig mod at reducere frafaldet.

For at tilgodese skoler med et større udgiftsbehov blev der med Finansloven for 2015 indført et socialt taxameter på de almengymnasiale uddannelser (stx og hf), de erhvervsgymnasiale uddannelser (hhx og htx) samt på erhvervsuddannelsernes tekniske, merkantile og SOSU-grundforl $\varnothing$ b. Det samlede bel $\varnothing b$, der omfordeles ved denne model, er ca. 200 mio. kr., som er tilvejebragt ved at reducere det ordinære undervisningstaxameter med ca. $2 \%$.

Det sociale taxameter er udmøntet gennem tre tillægstakster på 4.460 kr., 4.950 kr. og 5.350 kr. (2015 niveau), der gives til skoler, hvor mere end en vis andel af eleverne vurderes at være frafaldstruede. Takst 1 udbetales til skoler, der har mellem 43 og 50\% frafaldstruede elever, takst 2 udbetales til institutioner, der har mellem 51 og $60 \%$, og takst 3 udbetales til institutioner, hvor $61 \%$ eller derover af eleverne vurderes at være frafaldstruede. Det er således ikke den enkelte elev, som udløser et socialt taxameter, men sammensætningen af institutionens samlede elevgrundlag, der bestemmer institutionens takst.

Modellen for det sociale taxameter baseres på elevernes grundskolekarakterer. Valget af karakterer som udmøntningsgrundlag er truffet, idet analyser viser, at der er stor sammenhæng mellem en elevs afgangskarakterer fra grundskolen og samme elevs sandsynlighed for at fuldføre en ungdomsuddannelse. I den statistiske model, der ligger til grund for beregningen af det sociale taxameter, defineres en elev som frafaldstruet, hvis elevens fuldførelsessandsynlighed ligger under landsgennemsnittet på den pågældende uddannelse.

Kilde: Undervisningsministeriet (2014) samt Finansloven for 2015

Det er dog også muligt at anvende en risikojustering af tildelingen baseret på f.eks. en landspraksis, når der fastlægges en tildelingsmodel for f.eks. en bestemt kommune, således at det ikke er en konkret kommunes praksis, der reproduceres. Vi har ovenfor formuleret tildelingen til f.eks. distrikter således, at taksterne er konstante, og risikojusteringen foretages ved kapitatildeling. Som et alternativt eller supplerende perspektiv kunne én eller flere af taksterne risikojusteres eller justeres efter, hvilke aktiviteter de(n) dækker over. 
Hvis der er tale om en risikojustering på baggrund af individers karakteristika, vil dette normalt blive opfattet som en del af kapitatildelingen fremfor en risikojustering af taksten. Men der kan også være situationer, hvor man vælger at risikojustere taksttildelingen. Et eksempel er det sociale taxameter (se tekstboks 1), der blev indført på ungdomsuddannelsesområdet med Finansloven for 2015. I stedet for at tildele efter en fast takst pr. elev modtager uddannelserne i praksis tildeling efter en takst, der kan antage fire ${ }^{\mathrm{xii}}$ forskellige værdier afhængig af andelen af såkaldte frafaldstruede elever, der er optaget på skolen.

\section{Takster eller aktivitetsomkostninger?}

I princippet kan taksterne som anført af Bjørnenak (2000) opfattes som en form for aktivitetsomkostninger eller 'cost drivere'. Sådanne aktivitetsomkostninger kunne eksempelvis fastlægges ved hjælp af statistiske teknikker eller ved anvendelse af Activity-Based Costing (Bukh \& Israelsen 2004; Kaplan \& Cooper 1998). Formelbaserede finansieringsprincipper, og dermed også takstfastlæggelsen, er imidlertid baseret på en række andre hensyn end alene, hvilke faktorer der bedst kan forklare omkostningerne. Det er i særdeleshed også et spørgsmål om, hvilke af de formål, betaleren ønsker, der skal realiseres. Disse formål operationaliseres ved de mål, der indgår i finansieringsformlen.

Selvom antallet af administrative medarbejdere på en selvejende uddannelsesinstitution givetvis vil være en cost driver, skal antallet af administrative medarbejdere ikke nødvendigvis anvendes som et tildelingskriterie. Hvis ministeriet ønsker undervisning fremfor administration, foretrækkes normalt takstkategorier vedrørende undervisningen. Tilsvarende vil antallet af klasser være en væsentlig cost driver for en folkeskole, men hvis forvaltningen ønsker at reducere omkostningerne ved at øge klassestørrelsen, kan det vælges at lade elever indgå i tildelingsmodellen i stedet for klasser. Dermed er takstfastlæggelsen i en finansieringsformel beslægtet med Strategic Management Accounting (Bromwich \& Bhimani 1994), idet der her lægges vægt på "characteristics offered to the consumer each of which the customer is willing to pay for" (Bromwich \& Bhimani 1994, p. 139; jf. Bjørnenak 2000, p. 206).

Eksemplerne illustrerer såkaldte illegitime risikofaktorer eller cost drivere (f.eks. høje administrationsomkostninger eller lave klassestørrelser), som betaleren ikke ønsker at kompensere for ${ }^{\text {xii }}$ (Smith et al. 2001), fordi de repræsenterer uønskede udfald eller aktiviteter, samtidig med at disse kan påvirkes af decentrale beslutninger. Når det fastlægges, hvilke kriterier der indgår i en kapitatildeling, skal der på tilsvarende måde tages hensyn til, om disse afspejler legitime udgiftsbehov. 
Smith et al. (2001) angiver desuden, at kriterierne ideelt set skal opfylde kravene om, at der skal være konsistente data tilgængelige på individniveau, og at målingen af dem skal være fri for modstridende incitamenter. Endelig må målingen heller ikke være manipulerbar. Se også Magnussen (2010) samt Smith (2007, 2008). Det kan være en kompliceret proces at fastlægge finansieringsformler. Smith skriver direkte:

...the development of formulae is a bargaining process in which the constituent parties seek a compromise on issues such as the nature of the funding formulae, the sources of data, the analytic methods to be used, and the legitimate indicators of spending needs to be used in the formula. (Smith 2008 p. 16).

\section{Omkostningseffektivitet i tildelingsmodellen}

Det er et fællestræk for det arbejde, der pågår i regionerne omkring værdibaseret sundhed (Bjerregaard \& Christensen 2018; Refnov 2018), og de økonomimodeller, der introduceres i flere kommuners effektbaserede økonomistyring (Jensen \& Olesen 2018a, 2018b; Riise-Knudsen \& Kokholm 2018), at den økonomiske styring skal fremme omkostningseffektivitet. Det centrale ved dette begreb er, at det er en brøk: Vi sætter effekt i forhold til de omkostninger, der medgår til at skabe effekten. Kan der skabes bedre effekt for de tildelte ressourcer, bør man gøre det, og kan der skabes den samme effekt med færre ressourcer, er det også en god idé, da der er masser af andre opgaver, der også skal løses.

I sundhedsvæsnet refereres ofte til Porters (2010) værdibrøk (f.eks. Højgaard et al. 2016; Madsen et al. 2017), uden at denne operationaliseres fuldt ud. F.eks. skriver Højgaard et al. (2016) i en evaluering af de danske erfaringer med værdibaseret styring blot, at:

Værdi er her defineret som de opnåede sundhedsrelaterede effekter (outcome) i forhold til omkostninger... Ved sundhedsrelaterede effekter af betydning for patienten forstås den samlede effekt af det givne patientforløb... Ligeledes er det de totale omkostninger ved det samlede behandlingsforløb, der udgør nævneren i brøken. Større værdi af behandlingen kan således opnås ved enten at forbedre effekten (outcome) til samme omkostninger eller ved at opretholde effekten men bruge færre ressourcer (Højgaard et al. 2016, p. 27).

Der gemmer sig stor kompleksitet bag den overordnede målsætning om omkostningseffektivitet i alle dele af den offentlige sektor. Det opfattes eksempelvis ofte som vanskeligt at udvikle egnede mål for effekt, men det kan være endnu vanskeligere at opgøre relevante og præcise omkostninger ved det samlede forløb for enkelte borgere (Kaplan \& Porter 2011). For at udvikle en effektbaseret 
økonomisk styring, der understøtter det ledelsesmæssige fokus på omkostningseffektivitet, skal flere forhold afklares, og det skal vurderes, hvilke konsekvenser en ændring i økonomistyringen vil få. Det gælder ikke mindst spørgsmålet om, hvad der skal forstås ved et forløb, og hvilke omkostninger der medregnes.

Hertil kommer spørgsmålet om, hvordan effekter og omkostninger i relation til det ene individ afvejes i forhold til andre effekter og andre omkostninger for et andet individ. Hvis man f.eks. kan forøge livskvaliteten for borger A med 10\% ved at øge omkostningerne med $20 \%$ og forøge livskvaliteten for borger B med 40\% ved at forøge omkostningerne med 30\%, hvilke beslutninger skal denne information da give anledning til, hvis ressourcerne er begrænsede? Det afhænger både af, hvad det initiale omkostningsniveau er, og hvad livskvaliteten for de to borgere i udgangspunktet er. Derudover indebærer det en prioritering af de to borgeres livskvalitet i forhold til hinanden. Det er en prioritering, der under alle omstændigheder skal foretages, og som bliver gjort i dag. Hvis økonomistyringen skal fremme mere omkostningseffektivitet, skal prioriteringerne indgå i den økonomiske ressourcetildeling og dermed ekspliciteres.

\section{Langsigtethed i effektskabelsen}

Kommuner, der har erfaringer med at arbejde med effektbaseret økonomistyring, tager oftest udgangspunkt i, at budgettildelingsmodellerne så vidt muligt baseres på tildelingsprincipper, der fremmer omkostningseffektivitet. Tildelingsmodellerne indgår imidlertid i den flerperiodiske budgetstyring, hvor der bl.a. er behov for at kunne lave periodiske (normalt måneds- eller kvartalsvise) opfølgninger samt udføre korrigerende handlinger på baggrund af de periodiske opgørelser af forbrug samt prognoser (Heeager \& Olesen 2014, afsnit 8.4). Det kan være vanskeligt, idet kombinationen af afdelingsbudgetter baseret på kortsigtet, periodisk styring og budgetoverholdelse nemt kommer i konflikt med det mere langsigtede fokus på omkostningseffektivitet, hvis sidstnævnt reelt har et flerårigt fokus.

I sin yderste konsekvens betyder det flerperiodiske perspektiv eksempelvis, at effekten af indsatser i forhold til børn i dagtilbud burde vurderes i resten af livsforløbet. Det vil dog i sagens natur gøre det vanskeligt at operationalisere effekt i en økonomisk styringsmodel. Ud fra en pragmatisk betragtning vil man ofte fokusere på effekter, der er konstaterbare med en relativ kort tidshorisont, ligesom kun udvalgte effektmål indgår. Ligeledes vil effektstyring i sundhedsvæsnet indebære "tracking the expenses involved in treating the full condition over the full cycle of care" (Porter \& Lee 2013, p. 11), hvilket ofte indebærer ikke blot hospitalets og den praktiserende læges aktiviteter men også de kommunale indsatser. 
Det er velkendt, at det kan give styringsmæssige udfordringer, når flere afdelinger med separate budgetansvar skal samarbejde om at opnå fælles resultater. Udfordringerne bliver ikke mindre, når den økonomiske styring bliver interorganisatorisk og indebærer fælles bevillinger og budgetansvar på tværs af organisationer, som har separate ledelser, er forskellige myndigheder og er omfattet af forskellig lovgivning.

\section{Forløb og helhedsorientering}

Ud fra en ideel betragtning bør en virksomheds strategi og dens aktiviteter bestemme, hvordan virksomheden bedst muligt organiseres. For at sikre den bedst mulige ledelse vil det oftest være en fordel, at det ledelsesmæssige ansvar gøres så entydigt som muligt inden for rammerne af den valgte organisering - og for at den økonomiske styring kan understøtte organiseringen og ledelsesrollerne, vil man som udgangspunkt tilstræbe, at budgetansvaret følger organisations- og ledelsesstrukturen. Dette er intuitivt fornuftigt, men i praksis er aktiviteterne i de enkelte afdelinger ofte gensidigt afhængige af hinanden, og den organisering, der ud fra én betragtning er hensigtsmæssig, kan ud fra andre betragtninger gøre det vanskeligt for medarbejdere i forskellige afdelinger at samarbejde.

Mange kommuner arbejder i disse år med helhedsorienterede indsatser. Når det strategiske og faglige fokus ændres i retning af mere helhedsorientering, vil det være naturligt at overveje ændringer i organiseringen og placeringen af det økonomiske ansvar, således som Thorball (2018) eksempelvis beskriver det i relation til Københavns Kommunes indsatser på social- og arbejdsmarkedsområdet. Jo mere adskilt det økonomiske ansvar er, jo vanskeligere er det at få den helhedsorienterede indsats til at fungere - og jo vanskeligere er det at skabe en bedre sammenhæng ved at ændre på den økonomiske styring.

Inden for det enkelte udvalgsområde i en kommune vil det være nogenlunde håndterbart at skabe økonomisk sammenhæng mellem f.eks. dagtilbud og folkeskole ved enten at ændre på organiseringen, så der, fremfor at kommunen er opdelt på en måde i skoledistrikter og på en anden måde i dagtilbudsdistrikter, konstrueres én opdeling i 'lærings- og opvækstdistrikter' med fælles budgetansvar. Ligeledes er det, som Riise-Knudsen og Kokholm (2018) viser, muligt at udvikle en tildelingsmodel, der skaber incitamenter til samarbejde mellem skoler og dagtilbud, selvom budgetansvaret er separat.

Når der i en kommune skal skabes sammenhæng mellem aktiviteter, der indgår i separate bevillingsområder, øges kompleksiteten af den økonomiske styring. Det har fået nogle kommuner til at overveje ændringer af det politiske bevillingsniveau. Hvis bevillingsniveauet har været relativt lavt (jf. Heeager \& Olesen 2014, kapitel 6), vil et højere bevillingsniveau eller en ændring af enkelte opgavers placering betyde, at styringsmulighederne forbedres. Dette er eksempelvis tilfældet, når 
mange kommuner de senere år har flyttet Ungdommens Uddannelsesvejledning (UU) fra børne- og ungeområdet til arbejdsmarkedsområdet - og måske endda etableret et særskilt ungecenter, der samler både generelle arbejdsmarkedsindsatser for unge og UU i et fælles ledelses- og overordnet budgetansvar.

Hvad angår den nationale organisering af kommunale og regionale opgaver, så spiller den kommunale medfinansiering af sundhedsvæsnet en central rolle for at øge incitamenterne til samarbejde og sammenhæng i opgaveløsningen mellem kommuner og regioner. Udgangspunktet er her, at kommunerne betaler en andel af regionernes omkostninger til den enkelte behandling, herunder ambulante besøg. Dette skaber ganske vist incitamenter til at forebygge indlæggelser og til at udvikle indsatser, der ikke kræver kontakt til hospitalet, men det indebærer også en række andre incitamentsproblemer. Det skyldes bl.a., at regionernes økonomiske styring modsat kommunernes indebærer incitamenter til at øge aktiviteten på hospitalerne (jf. Refnov 2018).

\section{E. Lighed i finansieringsformlen}

Selvom vi i artiklen har fokus på omkostningseffektivitet som en form for universel målestok for kvaliteten af fordelingsmodellen, er det for det første vigtigt at være opmærksom på, at effekt ikke er et endimensionelt begreb. Det består af mange former, der måles på forskellige måder og $\mathrm{i}$ forskellige enheder. For det andet skal man være opmærksom på, at enhver ressourcetildeling indebærer en beslutning om, både hvilke effekter der prioriteres, og hvordan effekten for forskellige individer prioriteres. Det er ikke anderledes, når der anvendes formelbasereret finansiering, end hvis budgetterne fastlægges efter andre principper, men det bliver mere transparent og eksplicit, og derfor kan det synes mere kontroversielt, end det er.

\section{Værdier og prioritering}

Prioriteringen mellem forskellige individers behov er et spørgsmål om både omfanget og typen af lighed, der ønskes. Sædvanligvis (f.eks. Baker \& Green 2015; Magnussen 2010; Smith 2007; Rice \& Smith 2001a, 2001b) skelnes mellem horisontal lighed, der indebærer "equal treatment of equals" (Smith 2007, p. 34), og vertikal lighed, der betyder, at forskellige behov i en eller anden forstand skal imødekommes forskelligt. Disse to forskellige lighedsprincipper giver ikke nødvendigvis anledning til den samme fordeling af ressourcerne, og derfor vil der indgå forskellige komponenter med forskellige egenskaber i finansieringsformlerne.

Når Sundhedskoordinationsudvalget mellem Region Hovedstaden og kommunerne i regionen har visioner om at "skabe mere lighed i sundhed" (Sundhedskoordinationsudvalget 2018, p. 2) udtrykker det eksempelvis et ønske om bedre vertikal lighed, og derfor er strategien i regionen at "sætte 
særligt fokus på vores samarbejde omkring indsatser for de mest sårbare og udsatte borgere” (ibid.). Tilsvarende drejer det sig også om vertikal lighed, der skal skabe mere social mobilitet, når Csonka (2017) stiller spørgsmålet om, hvordan vi får mere lighed i uddannelse. Omvendt udtrykker det et ønske om større horisontal lighed, når Sundhedsministeriet (2015) udtrykker, at:

Patienterne har samme rettigheder i sundhedsvæsnet, men den geografiske ulighed i sundhed betyder, at ikke alle får deres ret, for i praksis får patienterne ikke de samme behandlingstilbud på tværs af landet. Det kan danskerne ikke være tjent med, og derfor er det også en bunden opgave, at forskellene i den geografiske ulighed i sundhed bliver mindre de kommende år. ${ }^{\text {xiv }}$

Der er ligeledes tale om et hensyn til større horisontal lighed, når alle skal have samme mulighed for adgang til f.eks. universitetsuddannelser, eller hvis der gives bevillinger til børnehaver, så alle kan opnå den samme personalenormering.

\section{Horisontal lighed}

Eksemplerne ovenfor illustrerer, hvad målsætninger om horisontal lighed kan indebære, hvis det styringsmæssige fokus i produktionsprocessen (jf. Bukh \& Christensen 2018c) placeres på input og aktiviteter. I sådanne situationer er betalerens præference at skabe lighed i input og dermed acceptere ulighed i effekten (Berne \& Steifel 1994, p. 406). Horisontal lighed kan imidlertid også betyde et ønske om at opnå samme effekt for individer, der er i samme omstændigheder, omend det kan være svært at operationalisere (jf. Smith 2007, p. 67).

Ud fra en horisontal betragtning bliver lighed ofte et spørgsmål om at tage hensyn til de faktorer, der anses for legitime årsager til, at den offentlige service er forskellig, og tilsvarende ikke inddrage de illegitime faktorer til serviceforskelle, når budgetterne fordeles. Hvis der er adgang til f.eks. udgiftsdata på individniveau, kan disse data, som Smith (2007, p. 68) også anfører, anvendes til at fastlægge en finansieringsformel ved statistisk at estimere de forventede individudgifter på baggrund af de individuelle karakteristika, der anses for legitime omkostningsdrivere.

Når alder inkluderes i de kommunale udligningssystemer, kan det eksempelvis ses som et udtryk for, at alder opfattes som en legitim udgiftsfaktor i relation til kommunernes ansvar for at finansiere ældrepleje, skoler, daginstitutioner m.v. Alder er ligeledes en legitim udgiftsfaktor i relation til sundhedsudgifterne i bloktilskudsmodellen, som finansierer regionerne. Der laves jævnligt beregninger af de faktiske forskelle i den offentlige service, kommunerne tilbyder, eller hvilket serviceniveau de enkelte kommuner har råd til, og dermed om de enkelte kommuners bloktilskud giver mulighed for at afholde et nogenlunde ens serviceniveau. Selvom der kan demonstreres 
forskelle, er det ikke ensbetydende med, at udligningsmodellen skal ændres, idet den grundlæggende afspejler et politisk valg om horisontal lighed.

\section{Vertikal lighed}

Ud fra et vertikalt lighedsprincip er der fokus på variationerne i effekt individer imellem. Dermed bliver det mere centralt, hvordan effekt skal måles. Hvis der kan fastlægges egnede effektmål, kan finansieringsformlen i princippet bestemmes ved at fastlægge, hvilke ressourcer der kræves for, at effekten for hvert enkelt individ bliver den samme. I praksis er det dog kompliceret, og der kan ofte ikke opnås en høj grad af vertikal lighed, selvom det måtte ønskes, simpelthen fordi alle er forskellige. Uanset hvilke ressourcer der måtte blive allokeret til offentlige indsatser, kan det næppe sikres, at alle opnår samme livskvalitet, da vertikal ulighed i høj grad skyldes ulige fordelinger af de sociale faktorer, der påvirker sundhed (Graham 2004; Bartley 2016; Asthana \& Gibson 2020). Tilsvarende gælder for de kommunale serviceområder, hvor individuelle forskelle også i høj grad påvirker f.eks. de resultater, der opnås i folkeskolen, eller de muligheder borgere med forskellige handicap får for at leve deres liv som alle andre osv.

Ikke desto mindre vil det ofte være et eksplicit hensyn i tildelingsmodellen, at der tildeles ressourcer, så det er muligt at opnå en vis grad af vertikal lighed. Eksempelvis kan tildelingen af ressourcer til specialundervisning i folkeskolen opfattes som et udryk for, at der tilstræbes vertikal lighed (jf. Baker \& Green 2015), hvad enten det sker ved, at forvaltningen finansierer udgifter til specialundervisning som en hel eller delvis takstfinansiering, eller at distriktsskolerne tildeles ressourcer, der tager hensyn til elevernes forventede behov for specialundervisning ved en kapitafinansiering.

Igennem årene har der været en gradvis ændring i etiske og politiske opfattelser fra et primært fokus på horisontal lighed til et større hensyn også til vertikale lighedsprincipper. Således fremhæver BenDavid-Hadar et al. (2018), at der har været et stigende hensyn til vertikal lighed i formelfinansiering på uddannelsesområdet. Se også Ross \& Levačić (1999). En tilsvarende udvikling ses i sundhedsvæsnet, hvor der i Danmark såvel som internationalt er stigende fokus på vertikal lighed i form af 'health equity' fremfor horisontal lighed i form af 'health care equity' (Asthana \& Gibson 2020).

\section{F. Direkte effektbaserede tildelingsmodeller}

Vi skelner mellem effektledelse og -styring på den ene side og effektbaseret økonomistyring på den anden side (jf. Christensen \& Bukh 2018). Hvad angår økonomistyringen, skelner vi mellem to former for effektbaseret økonomistyring - direkte og indirekte - afhængig af, om der direkte indgår 
effektmål i målstyringen og tildelingskriterierne. Når vi i denne artikel har fokus på tildelingsmodeller, drejer denne skelnen sig konkret om, hvorvidt der indgår effektmål som tildelingskriterie, og vi anvender derfor denne opdeling:

A. Effektledelse eller -styring: Et strategisk og ledelsesmæssigt fokus på effekt, evidens og virkningsfulde faglige indsatser, uden at der indgår effektmål i økonomistyringen. Dermed er der hverken tale om direkte eller indirekte effektbaseret økonomistyring.

B. Direkte effektbaserede tildelingsmodeller. For at kunne tale om en effektbaseret tildelingsmodel skal nogle af tildelingskriterierne være formuleret som effektmål fremfor input-, proces- og outcomemål.

C. Indirekte effektbaserede tildelingsmodeller. Hvis tildelingsmodellen er baseret på tilstrækkelige økonomiske incitamenter til at øge omkostningseffektivitet, anvender vi begrebet indirekte effektbaseret tildeling.

Normalt anvendes effektledelse og -styring (pkt. A), før det er relevant at overveje i hvilket omfang, der skal tages hensyn til effekt. Selvom vi ovenfor har skelnet mellem direkte og indirekte effektbaserede tildelingsmodeller (pkt. B og C), er det mere korrekt at tale om et kontinuum, således at der i større eller mindre grad kan anvendes effektmål i tildelingsmodellen. Det er dog ikke altid muligt at anvende effektmål i tildelingsmodellerne, og det er ikke altid hensigtsmæssigt. Derfor vil vi herunder ikke blot se på, hvordan effektmål indarbejdes i tildelingsmodellen, men også gå mere i detaljer med, hvornår direkte effektbaserede tildelinger med fordel kan anvendes.

Når bevillingskriterierne flyttes fra aktivitet og input til i højere grad at være baseret på output, eller endda effekt, øges ledelsesrummet, og der skabes dermed bedre mulighed for, at omkostningseffektiviteten kan øges, da mulighedsrummet samtidig udvides. Tildelinger efter effekt bringer målene tættere på betalerens målsætninger, end når der f.eks. tildeles efter output.

Outputbaserede tildelinger giver primært incitamenter til øget produktivitet. Når universiteter f.eks. tildeles ressourcer efter, hvor mange eksamener de studerende består, giver tildelingsmodellen incitamenter til at indrette undervisningen på en måde, så mange vil bestå. Da der ikke tildeles ressourcer til specifikke aktiviteter, vil modellen indeholde incitamenter til at reducere aktiviteter, der ikke er nødvendige for at bestå eksamenerne. Dermed giver outputbaserede tildelinger incitament til at øge produktiviteten, men de giver i sig selv ingen incitamenter til at forøge effekten af undervisningen i forhold til betalerens formål og f.eks. sikre, at de studerende får en god overgang til erhvervslivet (jf. Mouritsen 2018) eller kan varetage job, der er behov for. Det er derimod tilfældet, hvis effektmål indgår som eksplicitte tildelingskriterier. 


\section{Hvordan effekt kan indgå i tildelingsmodellen}

Når der anvendes en direkte effektbaseret tildeling, er grundprincippet, at en del af tildelingen gøres afhængig af, hvilken effekt der opnås. Afhængigt af hvilket tildelingsprincip der anvendes, kan enten den faste tildeling (F), taksttildelingen (T) eller kapitatildelingen (K) gøres (helt eller delvist) effektafhængig. Det er også muligt at anvende en effektbaseret tildeling, uden at alle tre tildelingskomponenter indgår i modellen. Det mest almindelige vil dog være, at der anvendes direkte effektbaseret tildeling i forbindelse med en takstkomponent. Dermed vil den takstafhængige komponent af tildelingen til enhed $i$, udover den sædvanlige takstkomponent, $T_{i}$, bestå af en effektkomponent, $E_{i}$, således at takstdelingen til område $i$ bliver:

$T_{i}+E_{i}=\sum t_{k} \times n_{k i}+\sum e_{k} \times E_{k i}$

hvor

$e_{k}=$ takst knyttet til effektmål $k$

$E_{k i}=$ effekten opnået af enhed $i$ for effektmål $k$.

Dermed er den direkte effektbaserede tildeling i princippet blot en udvidelse af den sædvanlige tildelingsmodel, jf. afsnit D, da der stadig kan indgå både en kapitatildeling og en fast tildeling. Ved anvendelse af effektmål kan der skabes en stærkere kobling mellem betalerens målsætninger, og de mål udførerne prioriterer. Hvis en kommune eksempelvis ønsker, at flere unge efter afsluttet folkeskole starter direkte i ungdomsuddannelse, kan ungdomsuddannelsesfrekvens, jf. tekstboks 2, anvendes som et effektmål i skoletildelingsmodellen. Hvis det mere specifikt prioriteres, at de unge skal tage erhvervsuddannelse, kan erhvervsuddannelsesfrekvens tilsvarende anvendes som effektmål. 
Tekstboks 2: Erhvervs- og ungdomsuddannelsesfrekvens

Målsætninger for unges uddannelse har været et politisk omdrejningspunkt i mange år. Ambitionen er, at alle unge i Danmark skal have en ungdomsuddannelse eller have tilknytning til arbejdsmarkedet. Andelen af unge, der starter (eller gennemfører) ungdomsuddannelser betegnes ofte ungdomsuddannelsesfrekvensen.

Derudover er det et politisk mål, at flere unge vælger en erhvervsuddannelse efter 9. og 10. klasse. De sidste par år (2018 og 2019) har omkring 20\% af eleverne i 9. og 10. klasse valgt en erhvervsuddannelse, når de søgte ud af grundskolen. Den procentandel, der vælger erhvervsuddannelse betegnes tilsvarende erhvervsuddannelsesfrekvens.

De gymnasiale ungdomsuddannelser er dog stadig de mest ansøgte ungdomsuddannelser, idet mere end $70 \%$ ans $\varnothing$ gte om en gymnasial ungdomsuddannelse. På kommunalt niveau ligger Læs $\varnothing$, Mors $\varnothing$, Stevns, Vejen og Odsherred alle med en søgefrekvens på over $30 \%$ til erhvervsuddannelserne. Og samlet set ligger i alt 31 kommuner over den politiske målsætning om, at $25 \%$ af en ungdomsårgang skal vælge en erhvervsuddannelse i forlængelse af 9. eller 10. klasse. Lavest ligger kommunerne Gentofte, Rudersdal og Hørsholm. Her søger kun henholdsvis 3,9, 4,5 og 6,0\% af eleverne mod erhvervsuddannelserne.

Tilsvarende kan der også være store variationer mellem skolerne i de enkelte kommuner.

Kilde: Børne- og Undervisningsministeriet, uvm.dk

Hvis alle enheder ikke har lige mulighed for at opnå effekt, vil der være risiko for, at en direkte effektstyring ikke skaber en ressourcefordeling, der sikrer den ønskede lighed og heller ikke fremmer den bedst mulige omkostningsfordeling. Eksempelvis vil der oftest være forskel på, hvilke forudsætninger og baggrund eleverne har skoledistrikterne imellem. Derfor vil det for det første være nødvendigt at justere effektmålet for elevsammensætningen. For det andet vil det være nødvendigt, at skolernes samlede tildeling er tilstrækkelig i forhold til udgiftsbehovet knyttet til den konkrete elevsammensætning.

I praksis vil det ofte være nødvendigt at tildele en del af ressourcerne efter et kapitaprincip og en anden del af ressourcerne efter takstprincipper (effekttakster og almindelige takster). Herudover kan der være mange situationer, hvor en aktivitetstakst ikke afspejler de marginale omkostninger ved at ændre aktiviteten, hvorfor modellen også kan forbedres ved at reducere taksten og indføre en fast komponent, således som det er tilfældet i det nye taxametersystem for de videregående uddannelser.

I udlandet er disse såkaldte Pay-for-Performance-modeller velkendte inden for sundhedssektoren (Eijkenaar et al. 2013; Langdown \& Peckham 2014; Scott et al. 2018), og den potentielle anvendelse i Danmark har været diskuteret i flere år (f.eks. Ankjær-Jensen \& Herbild 2008). Indtil videre er erfaringerne dog sparsomme herhjemme. I en oversigt over regionernes hidtidige erfaringer med værdibaseret styring (Højgaard et al. 2016) fremgår det eksempelvis, at hverken Hovedstaden, Midtjylland eller Nordjylland har indført nogen form for output- eller effektbaseret tildeling, 
omend Region Nordjylland dog eksperimenterer med det (jf. Bjerregaard \& Christensen 2018). Højgaard et al. (2016, p. 46) nævner, at Region Sjælland har knyttet tildelingsbaserede incitamenter til, at bestemte på forhånd fastlagte mål opnås, mens Region Syddanmark har gjort en tildeling på samlet set 2 mio. kr. afhængig af opfyldelsen af otte kvalitetsmål, hvoraf dog kun det ene er et reelt patientresultat. Med få undtagelser, se f.eks. Kortnum (2018) samt Jensen \& Olesen (2018b), er erfaringerne på andre områder også stadig relativt begrænsede i Danmark.

\section{Hvornår kan der anvendes direkte effektbaserede tildelinger?}

Ud fra betragtningen om at de mål, der tildeles ressourcer efter, får mere fokus end de mål, der ikke indgår i ressourcetildelingen, ville det være oplag i så stor udstrækning som muligt at anvende direkte effektbaseret styring. Herudover vil effektmål ofte være en bedre substitut for formål end aktivitetsmål. Derfor burde det give større sikkerhed for opnåelsen af betalerens formål, hvis der anvendes direkte effektbaserede tildelinger. Om det er tilfældet i praksis, er et spørgsmål om, i hvilken grad Smiths (2007, afsnit 1.4) fire institutionelle betingelser, som vi nævner i indledningen til denne artikel, er opfyldt.

Den første betingelse angiver, at der kan delegeres ansvar og beslutningskompetence til udføreren. Det drejer sig om, hvilke forhold der har betydning for graden af effektopnåelse, og hvor stor indflydelse udføreren har på effekten. Hvis effekten i for høj grad afhænger af forhold, der ikke kan påvirkes af udførerens beslutninger, vil det forøge bevillingsusikkerheden, når der indgår effektmål i tildelingsformlen. Sammenlignet hermed vil der oftere være mindre usikkerhed i relation til input eller aktiviteter. Det vil eksempelvis være nemmere at delegere ansvaret for at afvikle 100 undervisningstimer (aktivitet eller output) end at delegere ansvaret for, at eleverne udnytter deres potentiale bedst muligt, eller at de får en god overgang til ungdomsuddannelse (effekt).

Den noeste betingelse vedrører, om betalerens målsætninger kan operationaliseres til egnede effektmål, der afspejler den opgave, udføreren forventes at løse. I praksis kan det ofte være vanskeligt at fastlægge mål for alle de effekter, der ønskes, ligesom det kan være vanskeligt at måle den præcise effekt sammenlignet med f.eks. måling af aktiviteter og output. Som nævnt vil det være nemmere at måle, hvor mange undervisningstimer, der gennemføres, end om eleverne udnytter deres potentiale bedst muligt.

I forlængelse heraf indebærer det tredje krav, at betalingsformlen skal kunne specificeres ex ante, og der skal være egnede, verificerbare og rettidige data til rådighed, så formlen kan anvendes til at allokere ressourcer. For at kunne tildele efter effekt skal det kunne beregnes, hvordan tildelingen er afhængig af den effekt, der opnås, hvilket kun er muligt, hvis der i forvejen er effektdata til rådighed, så der kan etableres et tilstrækkeligt præcist sammenligningsgrundlag. Selvom der i princippet findes gode og præcise måder at måle, om eleverne udnytter deres potentiale, og selvom det 
besluttes at anvende disse målinger fremadrettet, kan der ikke udvikles en effektbaseret tildelingsmodel uden, at der findes resultater af denne måling i forvejen.

Herudover vil effektmål sammenlignet med f.eks. aktivitetsmål ofte være mere langsigtede, hvilket gør dem mindre anvendelige til at allokere ressourcer ex post. Eksempelvis kunne en god overgang til ungdomsuddannelserne operationaliseres ved, hvor stor en andel af eleverne, som 15 måneder efter 9. klasse er i gang med en ungdomsuddannelse (erhvervsfaglig uddannelse, gymnasial uddannelse, STU og KUU). Selvom dette effektmål er relevant, målbart og alment accepteret som et godt mål for unges overgang til ungdomsuddannelse, er det dog også påvirket af mange andre ting end folkeskolens indsats, og det måles med netop 15 måneders forsinkelse. Derfor er ungdomsuddannelsesfrekvens, jf. tekstboks 2, måske et bedre mål for (en del af) folkeskolens effekt.

Endelig angiver det fjerde krav, at betalingsformlen skal indebære tilstrækkelige incitamenter til, at udføreren præsterer i overensstemmelse med betalerens præferencer. Der er mange incitamenter, der påvirker de beslutninger, udføreren træffer; disse incitamenter interagerer, og mange af dem eksisterer uafhængigt af tildelingsmodellen. Man kan derfor ikke ved alene ved at se på komponenterne i den effektbaserede tildelingsmodel vurdere, om den indeholder tilstrækkelige incitamenter.

\section{Tekstboks 3: Faaborg-Midtfyn Kommune Strategi for effektbaseret styring}

Faaborg-Midtfyn Kommunes $\varnothing$ konomiske politik er sammensat af en række økonomiske mål. Flere af disse mål hviler på fire centrale delstrategier: "Strategi for basisbudgettering", "Strategi for effektivisering", "Strategi for aktiver og passiver" samt "Strategi for effektbaseret økonomistyring". I kommunens $\varnothing$ konomiske politik angives det, at de økonomiske mål og de fire strategier til sammen skal sikre en effektiv drift, et minimum af besparelser, en hensigtsmæssig incitamentsstruktur og et stabilt serviceniveau. Hvad angår Strategi for effektbaseret $\varnothing$ konomistyring, så angiver denne bl.a.:

Ved effektbaseret styring forstås styring efter de effekter, som kan dokumenteres, og som giver værdi for borgerne. Gennem en årrække har der været et stort fokus på inputsiden, hvor der stilles lighedstegn mellem afsatte ressourcer og leveret service. De leverede resultater har typisk fyldt mindre, mens de længerevarende effekter ofte har været helt fraværende. Der er i dag en erkendelse af, at fokus i højere grad bør rettes mod resultater og effekter.

Effektbaseret $\varnothing$ konomistyring går skridtet videre. Her gives de $\varnothing$ konomiske bevillinger med det formål at skabe gode resultater og en høj effekt fremfor at styre efter f.eks. normeringer og aktiviteter. Hvis modellen implementeres hensigtsmæssigt, kan det skabe et relevant fokus, øge innovationskraften, fremme omkostningseffektivitet og skabe flere frihedsgrader for lokale løsninger.

De økonomiske incitamenter er i sagens natur mere eksplicitte, når der anvendes direkte effektbaseret styring, mens de i højere grad er implicitte, når der anvendes indirekte effektbaseret 
styring. Som de institutionelle betingelser ovenfor viser, er der kompleksitet forbundet med direkte effektbaserede tildelingsmodeller, og det er nødvendigt med en vis grad af indsigt i både udvikling af tildelingsmodeller og i de konkrete styringsområder for at kunne udvikle en direkte effektbaseret tildelingsmodel. I praksis kan tildelingsmodeller være mere eller mindre effektbaserede, og man kan også, som Faaborg-Midtfyn Kommune (se tekstboks 3) opfatte effektbaseret styring som et perspektiv eller en strategi for den økonomiske styring.

Selvom de direkte effektbaserede tildelingsmodeller giver de klareste incitamenter til at opnå bedre effekt, så er det oftest nemmere at arbejde med indirekte effektbaserede tildelingsmodeller. I relation til regionernes igangværende arbejde med at skabe et mere værdibaseret sundhedsvæsen er der således et overvejende fokus på den indirekte effektbaserede styring, og direktøren for Danske Regioner skriver udtrykkeligt, at:

I udviklingen af fremtidens styring af sundhedsvæsenet skal målet først og fremmest være, at rammer og incitamenter ikke forhindrer, at personalet kan sætte fokus på de ting, som er vigtige for patienterne (Wolf 2018, p.11).

\section{Det nye samarbejdes potentiale prøves af}

Både den direkte og den indirekte effektbaserede økonomistyring kan opfattes som en form for resultatbudgettering, idet vi her oversætter ordet "performance" med resultat. OECD $(2005,2008)$ definerer denne styringsform relativt bredt, som "a form of budgeting that relates funds allocated to measurable results" (OECD 2005, p. 59). Mere præcist drejer resultatbudgettering ${ }^{\mathrm{xv}}$ sig om:

... public sector funding mechanisms and processes designed to strengthen the linkage between funding and results (outputs and outcomes), through the systematic use of formal performance information, with the objective of improving the allocative and technical efficiency of public spending (Robinson 2007, p. 1).

I de tilfælde, hvor der styres efter resultater i form af effekt, vil resultatbudgetteringen svare til direkte effektbaseret økonomistyring. Det vil imidlertid oftere være sådan, at de resultater, der styres efter i resultatbudgettering, reelt set ikke udgør effekt men snarere er udtryk for en form for aktivitets- eller outputbaseret budgetmodel, således som man kender fra finansieringen af videregående uddannelser både herhjemme og i udlandet (Herbst 2008; Natow 2016), eller en overordnet anvendelse af resultatkontrakter som illustreret af Ginnerup et al. (2007).

Vi vil kun anvende betegnelsen indirekte effektbaseret økonomistyring, hvis tildelingsmodellen indebærer "tilstrækkelige" incitamenter til at skabe effekt, selvom det er et vurderingsspørgsmål, hvornår incitamenterne er tilstrækkelige. Denne forskel på resultatbudgettering og effektbaseret 
økonomistyring betyder eksempelvis, at tildelinger baseret på taksterne i DRG-systemet kan opfattes som en resultatbaseret budgetmodel (Burau et al. 2018; Ginnerup et al. 2007; Jakobsen 2014; Jakobsen \& Pallesen 2017). Da tildelingskriteriet er aktiviteter - og netop ikke effekt - opfatter vi derimod ikke tildeling efter taksterne i DRG-systemet som effektbaseret økonomistyring.

Den såkaldte taxameterstyring af både ungdomsuddannelser (Hvidman \& Sievertsen 2014; Kortnum 2018) og videregående uddannelser er også udtryk for en resultatbaseret tildelingsmodel (Ginnerup et al. 2007). Uddannelserne tildeles primært ressourcer efter, hvor mange studerende der optages, men da ressourcerne på de videregående uddannelsesinstitutioner først udløses, når de studerende består eksamener, er incitamenterne både knyttet til at øge optag samt reducere dumpeprocenter. I en vis forstand kan begge dele være udtryk for kvalitet, men de resultater, der belønnes, kan også afspejle andre forhold, f.eks. at uddannelser er gjort spændende fremfor nyttige for at tiltrække så mange studerende som muligt, og/eller at det faglige niveau er reduceret fremfor at forbedre undervisningskvaliteten (jf. Produktivitetskommissionen 2013). Efter længere tids debat besluttede Folketinget i november 2017 derfor at reformere bevillingssystemet for de videregående uddannelser med henblik på at

... øge kvaliteten i uddannelserne og styrke det ledelsesmæssige fokus på god undervisning og en bedre overgang til job efter studierne. Partierne ønsker således et opgør med det snævre fokus på kvantitet i det videregående uddannelsessystem (Forlig 2017).

I det nye taxametersystem for de videregående uddannelser afhænger omkring 7,5 \% af undervisningsbevillingerne af beskæftigelse, færdiggørelse og kvalitet, men modellen er suppleret med restriktioner på, hvor meget de gamle bevillinger kan ændres som følge af den nye model, ligesom modellen har en forholdsvis lang indfasningsperiode. Herudover indgår der også faste tildelinger til de videregående uddannelsesinstitutioner. 


\section{Tekstboks 4: Den Bibliometriske Forskningsindikator}

Den Bibliometriske Forskningsindikator (BFI) har to formål. For det første skal den give et overblik over den danske forskningsproduktion, og for det andet er BFI en del af den resultatbaserede finansieringsmodel for nye basismidler og fordeler midler til danske universiteter baseret på produktionen af forskningspublikationer. Indikatoren beregnes årligt for hvert universitet som antallet af BFI-point, idet hver forskningspublikation giver et pointtal afhængig af, hvor den er publiceret.

For at en publikation kan udløse point, skal den leve op til BFI's definition af en forskningspublikation og være udgivet i en kanal, som er optaget på en af BFI-listerne. Formålet med BFI's definition af en forsknings-publikation er ikke at sige, hvad videnskab er eller bør være men har udelukkende det formål at beskrive typen af publikationer, der udløser point. I BFI niveauinddeles serier i tre niveauer (herunder tidsskrifter) og forlag i to niveauer. Jo højere niveau en kanal har, desto flere BFI-point udløser en publikation publiceret i kanalen.

For hver kanal opgøres det gennemsnitlige antal forskningspublikationer på et år; i BFI-sammenhæng kaldet verdensproduktionen. Antallet af serier, der kan være på niveau 1, 2 og eventuelt 3, er fastsat ud fra procentandelen af verdensproduktionen per fagområde, således at $80 \%$ af verdensproduktionen kan være på niveau 1, 17,5\% på niveau 2 og 2,5\% på niveau 3.

Publikationer på niveau 1 tildeles 1 point, publikationer på niveau 2 tildeles 3 point, mens publikationer på niveau 3 tildeles 5 point. Niveaudelingen belønner således universiteterne for, at medarbejderne publicerer i de mest prestigefyldte kanaler. Da pointene opgøres for de enkelte publikationer, kan der ligeledes beregnes BFI for de enkelte fakulteter og institutter, hvilket nogle universiteter anvender i den interne tildelingsmodel. Ligeledes anvendes BFI på mange inistitutter som grundlag for publiceringskrav til medarbejdere samt i personaleudviklingssamtaler.

Niveaudelingen af publikationerne afspejler en kvalitetsvurdering, som har en høj grad af sammenhæng med, hvor væsentlig forskningen er og dermed også, hvor mange andre artikler der kan forventes at henvise til publikationen i de kommende år. Men der er ikke tale om en effekt, hvorfor ressourcetildelingen efter BFI-point ikke er udtryk for effektbaseret $\varnothing$ konomistyring.

Kilde: https://ufm.dk/forskning-og-innovation/statistik-og-analyser/den-bibliometriske-forskningsindikator

Eksempelvis tildeles universiteterne en fast bevilling i form af såkaldte basismidler. Det skyldes, at en væsentlig del af universiteternes opgave er forskning, der ikke nødvendigvis har en direkte sammenhæng med de undervisningsrelaterede faktorer, der udløser bevillinger i taxametermodellen. En mindre del af universiteternes basismidler er imidlertid ikke faste men afhængig af mængden og kvaliteten af medarbejdernes publikationer målt ved den såkaldte BFIindikator, der ligesom i Norge (Sivertsen 2016) indgår som et resultatmål fremfor et effektmål, jf. tekstboks 4. Samlet set er det reelle omfang af direkte effektbaseret økonomistyring af de selvejende uddannelsesinstitutioner derfor begrænset, omend der er tiltag hertil.

Det skal også pointeres, at hverken effektbaseret styring eller resultatbudgettering må forveksles med den praksis, som Møller et al. (2016) gennemgik i den "relativt omdiskuterede rapport" (Andersen et al. 2017, p. 52) med titlen Review af resultatbaseret styring. Se også Møller \& Andersen (2017). I denne rapport blev resultatbaseret styring operationaliseret ved at anvende de engelske 
begreber performance management og performance measurement. Disse er imidlertid endnu bredere begreber, der, som anført af Broadbent \& Laughlin (2009, p. 284), kan have meget forskellige betydningervi. Derfor er det tvivlsomt, om der kan konkluderes noget generelt om, hvilke egenskaber resultatbaseret styring har ud fra denne operationalisering, hvilket også påpeges af Ejler (2017).

\section{G. Afsluttende bemærkninger}

Der er et politisk ønske om at sætte mål for, hvad der skal opnås i de offentlige virksomheder. Det er ikke uproblematisk, fordi de færreste målsætninger kan udtrykkes ved mål, uden at andre forhold udelades. Men mål kan også være en nødvendighed, når generelle og måske vagt udtrykte målsætninger skal kommunikeres. Det gælder i særdeleshed, når der i den offentlige sektor delegeres beslutningskompetence til geografiske områder, som f.eks. kommuner eller decentrale enheder, f.eks. skoler, universiteter og hospitaler. Vi har i artiklen haft fokus på den hierarkiske kobling mellem en betaler og det underliggende styringsniveau i form af udførerenheder, samt på hvordan denne kobling konstrueres gennem tildelingsmodeller. Dette indebærer bl.a., at betalerens målsætninger operationaliseres til mål, som udføreren har ansvar for, samt at betaleren på forhånd specificer betalingskriterierne ved en matematisk formel, således at denne formel bestemmer ressourceallokeringen til udførerenheden. Dermed har betaleren både mulighed for at udtrykke målsætninger ved, at der formuleres mål for de opgaver, udføreren skal løse, og ved at der indgår mål i betalingsformlen.

Når der anvendes direkte effektbaserede tildelinger, indgår der effektmål i betalingsformlen. Dermed bliver omkostningseffektivitet et mål for udførerenheden og de mål, som udføreren arbejder efter, kommer tættere på betalerens målsætninger, end når der tildeles efter aktiviteter eller output. Derfor bør mål, så vidt det er muligt, formuleres med udgangspunkt i effekt fremfor f.eks. hvilke aktiviteter, der skal udføres. Den økonomiske styring, og ikke mindst tildelingsmodellen, har stor betydning for, hvilket ansvar og hvilke muligheder de enkelte decentrale enheder har for at skabe effekt. Det centrale kriterie i en effektbaseret økonomistyringsmodel er omkostningseffektivitet, og vi har derfor skitseret, hvordan forskellige former for tildelingskriterier har potentialet til at skabe incitamenter, der understøtter effektbaserede strategier og mål.

Vi har kun begyndende erfaringer fra danske offentlige virksomheder med at udvikle effektbaserede økonomistyringsmodeller. Effektbaseret økonomistyring indebærer både anvendelse af en række helt nye elementer samt elementer, der også anvendes af andre offentlige virksomheder, uden at disse teknikker i sig selv forbindes med effektbaseret økonomistyring. Det afgørende er, hvordan teknikkerne anvendes og kombineres. Hertil kræves et samlet design i forhold til den konkrete 
virksomheds krav til økonomistyringen. Derfor skal vi ikke fokusere på, hvor forskellighederne er i modellerne - men snarere på hvor sammenhængene og synergien er.

Nye styrings- og tildelingsprincipper ændrer principperne for, hvordan der tildeles ressourcer til at løse opgaverne i de forskellige dele af organisationen. Det betyder ofte, at der skal arbejdes på nye måder og i retning af mål, der tidligere enten var mindre centrale eller måske slet ikke i fokus. Det betyder forandringer i organisationen, og der kan være brug for nye kompetencer - ikke nødvendigvis nye medarbejdere men nye arbejdsmåder - mens andre færdigheder og kompetencer får mindre betydning. Det er alle ikke lige godt rustet til, og reaktionerne politisk såvel som i organisationen kan være svære at forudse.

En ny tildelingsmodel, der ændrer principperne for den økonomiske tildeling, kan også ændre de budgetter, som de enkelte afdelinger har til rådighed. Det kan komme som en overraskelse for nogen, selvom det egentlig burde være klart nok, at en "ny tildelingsmodel" kan indebære en ny fordeling af de økonomiske ressourcer. Det kan afføde reaktioner, der handler mere om konsekvenserne af modellen end de principper, den baserer sig på. Den organisatoriske adfærd omfatter ikke blot, hvordan den enkelte medarbejders attitude og intentioner påvirker den måde, medarbejderen tænker og agerer på, men også, hvordan interaktionen mellem menneskelig adfærd og forskellige sociale, politiske og økonomiske betingelser påvirker hinanden. 


\section{Referencer}

Andersen, L. B., C. Greve, K. K. Klausen \& J. Torfing. (2017). Offentlige styringsparadigmer: Konkurrence og sameksistens. København: Jurist- og Økonomiforbundets Forlag.

Andersson, M., T. Karlsson \& G. Kastberg. (2019). Värdebaserad vård: En kritisk granskning av konceptet och befintliga erfarenheter. Kommunforskning i Västsverige, KFi-rapport nr. 154.

Ankjær-Jensen, A. \& L. Herbild. (2008). Betaling for kvalitet: Økonomiske incitamenter til fremme af kvalitetsudviklingen i sundhedsvæsenet, Dansk Sundhedsinstitut, DSI rapport 2008.

Anthony, R. \& V. Govindarajan. (2006). Management Control Systems, 12. udgave, New York: McGraw-Hill.

Asthana, S. \& A. Gibson. (2020). The National Health Service (NHS) in 'crisis': the role played by shift from horizontal equity to vertical principles of equity. Health Economics, Policy and Law. Vol. 15, No. 1, pp. 1-17. https://doi.org/10.1017/s1744133118000361

Baker, B. D. \& P. C. Green. (2015). Conceptions of equity and adequacy in school finance. I Handbook of research in education finance and policy, 2nd edition, H. F. Ladd \& E. B. Fiske (eds.), pp. 231-243, New York: Routledge. https://doi.org/10.4324/9780203961063.ch12

Bartley, M. (2016). Health inequality: an introduction to concepts, theories and methods, 2nd edition. Cambridge: Polity Press.

Bedford, D. S., T. Malmi \& M. Sandelin (2016). Management control effectiveness and strategy: An empirical analysis of packages and systems. Accounting, Organizations and Society, Vol. 51, No. 1, pp. 12-28. https://doi.org/10.1016/j.aos.2016.04.002

BenDavid-Hadar, I., S. Case \& R. Smith. (2018). School funding formulae: design to create a learning society. Compare, Vol. 48, No. 4, pp. 553-570. https://doi.org/10.1080/03057925.2017.1323625

Berne, R. \& L. Steifel. (1994). Measuring Equity at the School Level: The Finance Perspective.

Educational Evaluation and Policy Analysis. Vol. 16, No. 4, pp. 405-421.

https://doi.org/10.3102/01623737016004405

Bjerregaard, H. H. \& P. H. Christensen. (2018). Værdibaseret styring af ortopædkirurgien i Region Nordjylland. I Strategi og styring med effekt, P. N. Bukh \& K. S. Christensen (eds.). København: Djøf Forlag.

Bjørnenak, T. (2000). Understanding cost differences in the public sector: A cost driver approach. Management Accounting Research, Vol. 11, pp. 193-211. https://doi.org/10.1006/mare.2000.0128 
Bleyen, P., D. Klimovsky, G. Bouckaert \& C. Reichard. (2017). Linking Budgeting to Results? Evidence about Budgeting in European Municipalities based on a Comparative Model. Public Management Review, Vol. 19, No. 7, pp. 932-953.

https://doi.org/10.1080/14719037.2016.1243837

Boll, J. \& L. Høeberg. (2013). Performance Management and Evaluation in the Danish Public Employment Service. I Performance Management and Evaluation: New Directions for Evaluation, S. B. Nielsen \& D. E. K. Hunter (eds.), Vol. 137, pp. 57-67. https://doi.org/10.1002/ev.20046

Bonde, M., C. Bossen \& P. Danholt. (2018). Translating value-based health care: an experiment into healthcare governance and dialogical accountability. Sociology of Health \& Illness, Vol. 40, No. 7, pp. 1113-1126. https://doi.org/10.1111/1467-9566.12745

Broadbent, J. \& R. Laughlin. (2009). Performance Management Systems: A Conceptual Model. Management Accounting Research, Vol. 2, No. 4, pp. 283-295.

https://doi.org/10.1016/j.mar.2009.07.004

Bromwich, M. \& A. Bhimani. (1994). Management Accounting: Pathway to progress. London: CIMA Publishing.

Bukh, P.N. (2005). Budgetlægningen i stormvejr: Er Beyond Budgeting et alternativ? Økonomistyring \& Informatik Vol. 21, No. 2, pp, 121-141.

Bukh, P. N. (2008). Design af økonomistyring: Balanced Scorecard eller budgetlægning. Økonomistyring \& Informatik, Vol. 24, No. 2, pp. 201-231.

Bukh, P. N. (2009). Design af økonomistyring: Principper og modeller. I Controlleren, P. N. Bukh (ed.). København: Børsen Forum.

Bukh, P. N. \& K. S. Christensen (2018a). Ledelsesrummet er et ansvar - og det vokser. Offentlig Ledelse, nr. 2/2018.

Bukh, P. N. \& K. S. Christensen (2018b). Strategi og styring med effekt: Danske erfaringer. København: Djøf Forlag.

Bukh, P. N. \& K. S. Christensen (2018c). Effektbaseret Økonomistyring. Nordisk Administrativt Tidsskrift, Vol. 95, No. 2, pp. 53-66.

Bukh, P. N. \& K. S. Christensen. (2019). Fremtidens økonomistyring er effektbaseret. Administrativ Debat, januar/2019, pp. 23-26.

Bukh, P. N. \& K. S. Christensen. (2020). Effektbaserede tildelingsmodeller: erfaringer og principper. Bringes i Samfundslederskab i Skandinavien. 
Bukh, P. N. \& P. Israelsen. (2004). Activity Based Costing - Dansk økonomistyring under forvandling. København: Jurist- og Økonomforbundets Forlag. https://doi.org/10.7146/politica.v20i1.68960

Bukh, P. N. \& A. K. Svanholt (2019). Styring i spændingsfeltet mellem vilde problemer og stramme budgetter. Samfundslederskab i Skandinavien, Vol. 34, No. 3, pp. 229-266.

https://doi.org/10.22439/sis.v34i3.5812

Bukh, P. N. \& A. K. Svanholt (2020). Empowering middle managers in social services using management control systems. Bringes i Journal of Public Budgeting, Accounting \& Financial Management. https://doi.org/10.1108/jpbafm-06-2019-0096

Bukh, P. N., K. S. Christensen \& A. K. Svanholt (2020). Omkostningsbevidsthed i socialt arbejde: fra spændingsfelt til professionalisme. Bringes i Tidsskrift for Professionsstudier.

Burau, V., H. M. Dahl, L. G. Jensen \& S. Lou. (2018). Beyond activity based funding: An experiment in Denmark. Health Policy, Vol. 122, p. 714-721. https://doi.org/10.1016/j.healthpol.2018.04.007

Callon, M. (1998). An essay on framing and overflowing: economic externalities revisited by sociology i The Laws of the Markets, M. Callon (Ed.), pp. 244-69. Oxford: Blackwell. https://doi.org/10.1111/j.1467-954x.1998.tb03477.x

Christensen, K. S. \& P. N. Bukh. (2018). Effektbaseret økonomistyring på vej i den offentlige sektor. Revision \& Regnskabsvoesen, nr. 8, pp. 28-41.

Clark, C., C. E. Menifield \& L. M. Stewart. (2017). Policy diffusion and performance-based budgeting. International Journal of Public Administration, Vol. 29, No. 1, pp. 51-77.

Csonka, A. (2017). Hvordan får vi mere lighed i uddannelse? København: Informations Forlag.

Cullen, J. B. (2003). The impact of fiscal incentives on student disability rates. Journal of Public Economics, Vol. 87, pp. 1557-1589. https://doi.org/10.1016/s0047-2727(01)00203-1

Danske Regioner. (2016). Beskrivelse af afregningsmodeller til at understøtte værdibaseret styring. Arbejdspapir, Arbejdsgruppen for økonomi, afregningsmodeller og data i projektet om værdibaseret styring, Danske Regioner, december 2016.

Deschamps, C. (2019). Stages of management control in large public organizations: From top to frontline managers. Journal of Management Control, Vol. 30, No. 2, pp. 153-184.

https://doi.org/10.1007/s00187-019-00282-z

Downes, T. A. \& L. Stiefel. (2015). Measuring equity and adeqacy. I Handbook of research in education finance and policy, 2nd edition, H. F. Ladd \& E. B. Fiske (eds.), pp. 244-259. New York: Routledge. 
Dooren, W. V., G. Bouckaert \& J. Halligan. (2015). Performance Management in the Public Sector, 2nd edition. London: Routledge.

Eijkenaar, F., M. Emmert, M. Scheppach \& O. Schöffski. (2013). Effects of pay for performance in health care: a systematic review of reviews. Health Policy, Vol. 110, No. 2-3, pp. 115-130. https://doi.org/10.1016/j.healthpol.2013.01.008

Ejler, N. (2017). Faglig ledelse mellem kerneopgave og styring. København: Djøf Forlag.

Ejler, N. \& H. R. Seiding. (2011). Performance Management: Værdiskabelse i den offentlige sektor med fokus på effekter og effektiv ressourceallokering. I Offentlig Ledelse, P. N. Bukh (ed.). København: Børsen Forum.

Ejler, N., H. R. Seiding, D. S. Bojsen, S. B. Nielsen \& F. Ludvigsen (eds.). (2008). Når måling giver mening: Resultatbaseret styring og dansk velfoerdspolitik. København: Jurist- og Økonomforbundets Forlag. https://doi.org/10.7146/politica.v20i1.68960

Ferreira, A. \& D. Otley. (2009). The design and use of performance management systems: An extended framework for analysis. Management Accounting Research, Vol. 20, No. 4, pp. 263-282. https://doi.org/10.1016/j.mar.2009.07.003

Forlig (2017). Nyt bevillingssystem for de videregående uddannelser ", forlig mellem Regeringen (Venstre, Liberal Alliance og Det Konservative Folkeparti), Socialdemokratiet, Dansk Folkeparti, Enhedslisten, Alternativet, Radikale Venstre og Socialistisk Folkeparti om en reform af bevillingssystemet for de videregående uddannelser (24. november 2017).

https://doi.org/10.7146/lom.v9i15.23126

Frow, N., D. Marginson \& S. Ogden (2010). Continuous' budgeting: Reconciling budget flexibility with budgetary control. Accounting, Organizations and Society, Vol. 35, No. 4, pp. 444-461. https://doi.org/10.1016/j.aos.2009.10.003

Gaarde, S. \& A. D. Lønbæk. (2018). Effekt i fokus: Erfaringer fra Odense Kommune. I Strategi og styring med effekt, P. N. Bukh \& K. S. Christensen (eds.). København: Djøf Forlag.

Ginnerup, R., T. B. Jørgensen, A. M. Jensen \& N. Refslund. (2007). Performance Budgeting in Denmark. OECD Journal of Budgeting, Vol 7, No. 4, pp. 1-24. https://doi.org/10.1787/budget-v7art20-en

Graham, H. (2004). Social determinants and their unequal distribution: clarifying policy understandings. The Milbank Quaterly, Vol. 82, pp. 101-124. https://doi.org/10.1111/j.0887378x.2004.00303.x

Heeager, A. \& J. M. Holm (2019). Hvordan modtager folkeskoler økonomiske ressourcer, og hvilken betydning har det? Politica, Vol. 51, No. 2, pp. 211-230. 
Heeager, A. \& S. J. Olesen. (2014). Kommunal Økonomi: Rammer, valgmuligheder og styring. København: Systime.

Heinesen, E. \& C. Kolodziejczyck. (2008). Statistisk model for udgifter vedrørende børn og unge med særlige behov. AKF Working Paper.

Hengel, H. van der, T. Budding \& T. Groot. (2014). Loosely Coupled Results Control in Dutch Municipalities. Financial Accountability \& Management, Vol. 30, No. 1, pp. 49-74.'

https://doi.org/10.1111/faam.12027

Herbst, M. 2008. Financing Public Universities: The Case of Performance Funding, New York: Springer-Verlag

Holmgaard, A. P. (2014). Velfoerd under opbygning: Fra Service til selvstoendighed. København: Gyldendal Public.

Hvidman, U. \& H. H. Sievertsen. (2014). Det økonomiske fundament: Finansiering og faktorer med betydning for omkostningerne. I Styring, ledelse og resultater på ungdomsuddannelserne, L. B. Andersen, P. Bogtoft, J. G. Christensen \& T. Tranæs (eds.), pp. 75-92. Odense: Syddansk Universitetsforlag.

Hunter, D. E. K. \& S. B. Nielsen. (2013). Performance Management and Evaluation: Exploring Complementarities. I Performance Management and Evaluation: New Directions for Evaluation, S. B. Nielsen \& D. E. K. Hunter (eds.), Vol. 137, pp. 7-17. https://doi.org/10.1002/ev.20042

Højgaard, B., R. T. Wolf \& M. Bech. (2016). Alternative styrings- og afregningsmodeller for sygehuse med afsæt i værdibaseret styring: En kortlægning af regionale forsøg og ordninger. KORA, december 2016.

Højgaard, B., J. Kjellberg \& M. Bech. (2018). Den statslige styring af det regionale sundhedsvæsen: Analyse af centrale instrumenter. Rapport, VIVE, april 2018.

Jakobsen, S. T. (2017). Specialundervisningsbehov i Vordingborg Kommunes skoledistrikter. En socioøkonomisk tildelingsmodel. Det Nationale Institut for Kommuners og Regioners Analyse og Forskning. København.

Jakobsen, M. L. F. (2014). The Partial Adoption of Performance Budgeting at Danish Hospitals. Danish Journal of Management \& Business, No. 3/4, pp. 79-97.

Jakobsen, M. L. F. \& T. Pallesen. (2017). Performance Budgeting in Practice: the Case of Danish Hospital Management. Public Organization Review, Vol. 17, No. 2, pp. 255-273.

https://doi.org/10.1007/s11115-015-0337-8

Jensen, P. M. (2018). Her er mindst én god grund til at elske værdibaseret styring. Tidsskrift for Dansk Sundhedsvoesen, Vol. 94, No. 2, pp. 20-25. 
Jensen, T. K. \& K. D. Olesen. (2018a). Det effektbaserede styringsparadigme i Odense Kommune. I Strategi og styring med effekt, P. N. Bukh \& K. S. Christensen (eds.). København: Djøf Forlag.

Jensen, T. K. \& K. D. Olesen. (2018b). Design og test af effektbaserede økonomimodeller. I Strategi og styring med effekt, P. N. Bukh \& K. S. Christensen (eds.). København: Djøf Forlag.

Jørgensen, T. S., J. J. Lykkegaard, A. Hansen, H. M. Schrøder, B. Stampe, A.-M. Tetsche Sweeney, B. A. Esbensen, B. Bech, K. Christensen, E. Friis-Mikkelsen, H. Røgind, T. Lundbak, P. C. Taylor, I. F. Petersson, E. E. Wæhrens, J. Kjellberg, H. Gudbergsen, L. E. Kristensen. (2018). Protocol for evaluating and implementing a pragmatic value-based healthcare management model for patients with inflammatory arthritis: a Danish population-based regional cohort and qualitative implementation study. BMJ Open, Vol. 8, No. 10, pp. 1-9. https://doi.org/10.1136/bmjopen-2018$\underline{023915}$

Kaplan, R. S. \& R. Cooper. (1998). Cost and effect: using integrated cost systems to drive profitability and performance. Harvard Business School Press: Boston, MA.

https://doi.org/10.1080/13675569808962056

Kaplan, R. S. \& M. E. Porter. (2011). How to solve the cost crisis in health care. Harvard Business Review, Vol 89, No. 9, pp. 47-64.

Kerr, S. (1975). On the Folly of Rewarding A, While Hoping for B. Academy of Management Journal, Vol. 18, No. 4, pp. 769-783. https://doi.org/10.5465/255378

KL. (2019). Budgetvejledning 2020, skrivelse 5-9, Supplementsskrivelse vedr. voksenhandicappede mv., KL, den 16. september 2019.

Kolk, B. Van der (2019). Management control packages: a literature review and guidelines for public sector research. Public Money \& Management, Vol. 39, No. 7, pp. 512-520.

https://doi.org/10.1080/09540962.2019.1592922

Kolk, B. van der \& T. Schokker. (2016). Strategy implementation through hierarchical couplings in a management control package: An explorative case study. Journal of Management Control, Vol. 27. No. 2, pp. 129-154. https://doi.org/10.1007/s00187-015-0226-X

Kortnum, A. A. (2018). Frafald på ungdomsuddannelserne. I Strategi og styring med effekt, P. N. Bukh \& K. S. Christensen (eds.). København: Djøf Forlag.

Kristensen, S. (2018). Differentieret budgettildeling som styringsværktøj og dialogredskab. I Strategi og styring med effekt, P. N. Bukh \& K. S. Christensen (eds.). København: Djøf Forlag. 
Langdown, C. \& S. Peckham. (2014). The use of financial incentives to help improve health outcomes: is the quality and outcomes framework fit for purpose? A systematic review, Journal of Public Health, Vol. 36, No. 2, pp. 251-258. https://doi.org/10.1093/pubmed/fdt077

Lewis, R., D. A. Brown \& N. C. Sutton. (2019). Control and empowerment as an organizing paradox: implications for management control systems. Accounting, Auditing and Accountability Journal, Vol. 32, No. 2, pp. 483-507. https://doi.org/10.1108/aaaj-11-2017-3223

Louis, T. A., T. B. Jabine \& M. Gerstein. (2003). Statistical issues in allocating funds by formula. Washington DC: National Academies Press.

Lundkvist, M. \& N. Vedsted. (2016). New public leadership: Fra strategi til effekt. København: Juristog Økonomforbundets Forlag.

Madsen, M. H., I. Bolvig, B. Højgaard \& J. Kjellberg. (2017). Evaluering af Udviklingshospital Bornholm: Betydningen af en ændret økonomisk rammemodel. KORA, juni 2017.

Magnussen, J. (2010). Equal access for equal need? Constructing and implementing a capitationbased formula for the distribution of health care resources in Norway, International Journal of Circumpolar Health, Vol. 6, No. 5, pp. 448-461. https://doi.org/10.3402/ijch.v69i5.17690

Malmi, T. \& D. A. Brown. (2008). Management control systems as a package - Opportunities, challenges and research directions. Management Accounting Research, Vol. 19, No. 4, pp. 287-300. https://doi.org/10.1016/j.mar.2008.09.003

Mauro, S. G., L. Cinquini \& G. Grossi. (2017). Insigths into Performance-based Budgeting in the Public Sector. A literature review and a research agenda. Public Management Review, Vol. 19, No. 7, pp. 911-931. https://doi.org/10.1080/14719037.2016.1243810

Mayston, D. J. (1998). Devolved Budgeting, Formula Funding and Equity. Management Accounting Research, Vol. 9, pp. 37-54. https://doi.org/10.1006/mare.1997.0069

Mejdahl, C. T., L. M. V. Schougaard, N. H. Hjollond, E. Riskjær \& K. Lomborg. (2018). Exploring organisational mechanism in PRO-based follow-up in routine outpatient care - an interpretive description of the clinical perspective. BMC Health Services Research, 18:546.

https://doi.org/10.1186/s12913-018-3352-y

Melander, P. (1994). Økonomistyringens dilemmaer og drivkræfter - fra økonomisk beslutningslogik til politisk multicentreret kamparena. Ledelse \& Erhvervsøkonomi, Vol. 58, No. 3, pp. 151-168.

Moss-Bjerre, M., J. Ibsen \& M. Ibsen. (2010). Resultatbaseret styring i kommuner. Samfundsøkonomen, nr. 6/2010, pp. 33-38. 
Mouritsen, J. (2016). Fra virksomhed til tal og retur: hvordan hænger økonomiske kendsgerninger og ledelsesmæssige hensyn sammen. I Produktion og styring: Perspektiver på økonomistyringen, P. N. Bukh \& T. B. Kristensen (eds.). København: Djøf Forlag.

Mouritsen, J. (2018). Formål og mål i New Public Management - ressource, begrænsning, trivialitet eller byrde? Samfundslederskab i Skandinavien, Vol. 33, No. 3, pp. 222-18

https://doi.org/10.22439/sis.v33i3.5551

Møller, M. Ø., K. Iversen \& V. N. Andersen. (2016). Review af resultatbaseret styring:

Resultatbaseret styring på grundskole-, beskæftigelses- og socialområdet. Det Nationale Institut for Kommuners Analyse og Forskning, København.

Møller, M. Ø. \& V. N. Andersen. (2017). Resultatbaseret statsstyring af lokal kernevelfærd. Politik, Vol. 20, No. 2, pp. 50-67. https://doi.org/10.7146/politik.v20i2.27653

Natow, R.S., V. Reddy, L. Pheatt 2016. Performance Funding for Higher Education , Baltimore: John Hopkins University Press.

Nielsen, S. B. \& N. Ejler. (2008). Improving Performance? Exploring the Complementarities between Evaluation and Performance Management. Evaluation, Vol. 4, No. 2, pp. 171-192.

https://doi.org/10.1177/1356389007087538

Nielsen, S. B., M. N. Jacobsen \& M. Pedersen. (2005). Øje for effekterne: resultatbaseret styring kan styrke offentlige indsatser. Nordisk Administrativt Tidsskrift, Vol. 86, No. 4. pp. 276-295.

Oates, W. E. (1999). An Essay on Fiscal Federalism. Journal of Economic Literature, Vol. 37, No. 3, pp. 1120-1149. https://doi.org/10.1257/jel.37.3.1120

OECD. (2005). Modernising Government: The Way Forward. Paris: OECD Publishing.

OECD. (2008). Performance Budgeting: A Users' Guide, Organization for Economic Co-operation and Development, Policy Brief, marts 2008.

Otley, D. (1999). Performance Management: A Framework for Management Control Systems

Research. Management Accounting Research, Vol. 10, No. 4, pp. 363-382.

https://doi.org/10.1006/mare.1999.0115

Petersen, J. S. \& K. Lemvig. (2018). Analyse af ressourcestyringsmodellen i Ballerup Kommune. Det Nationale Forsknings- og Analysecenter for Velfærd, København.

Petersen, J. S. \& T. A. Bæk. (2018). Specialundervisningsbehov i Helsingør Kommunes skoledistrikter. Det Nationale Forsknings- og Analysecenter for Velfærd, København.

Porter, M. E. (2010). What is Value in Health Care? The New England Journal of Medicine, No. 363, pp. 2477-2481. 
Porter, M. E. \& E. O. Teisberg. (2006). Redefining Health Care: Creating Value-Based Competition on Results. Boston: Harvard Business School Press. https://doi.org/10.1108/17506120810865442

Porter, M. E. \& T. H. Lee. (2013). The strategy that will fix health care. Harvard Business Review, Vol. 91, No. 10, pp. 50-70.

Poulsen, M. L., P. N. Bukh \& K. S. Christensen. (2020). Incentives and effects of test-based performance funding of Danish basic education schools. Working Paper, Institut for Økonomi, Aarhus Universitet.

Produktivitetskommissionen. (2013). Styring, ledelse og motivation i den offentlige sektor, analyserapport 3, september 2013.

PWC \& McKinsey. (2018). Analyse af den regionale styring på sygehusområdet. Rapport for Sundheds- og Aldreministeriet, Finansministeriet, Økonomi- og Indenrigsministeriet og Danske Regioner. PWC og Mckinsey \& Company, april 2018. https://doi.org/10.7146/aul.177.137

Refnov, J. (2018). Værdibaseret finansiering og afregning i sundhedsvæsenet. I Strategi og styring med effekt, P. N. Bukh \& K. S. Christensen (eds.). København: DJØF Forlag.

Rice, N. \& P. C. Smith. (2001a.) Capitation and risk adjustment in health care financing: an international progress report. The Milbank Quaterly, Vol 79, No, 1, pp. 81-113.

https://doi.org/10.1111/1468-0009.00197

Rice, N. \& P. C. Smith. (2001b). Ethics and geographical equity in health care. Journal of Medical Ethic, Vol. 27, No. 4, pp. 256-261.

Riise-Knudsen, S. H. \& S. Kokholm. (2018). På vej mod effektbaseret styring af folkeskolen: Erfaringer fra Vordingborg Kommune. I Strategi og styring med effekt, P. N. Bukh \& K. S. Christensen (eds.). København: Djøf Forlag.

Robinson, M. (2007). Performance Budgeting Models and Mechanisms. I Performance Budgeting: Linking Funding and Results, M. Robinson (ed.). Houndsmills: Palgrave Macmillan. https://doi.org/10.1057/9781137001528_1

Ross, K. N. \& Levacic, R. (eds.). (1999). Needs-based resource allocation in education via formula funding of schools. Paris: IIEP-UNESC.

SBU. (2018). Värdebaserad vård - kartläggning av kunskapsläget. Stockholm: Statens beredning för medicinsk och social utvärdering (SBU), SBU-rapport nr 285, Stockholm.

Scott, A., M. Liu \& J. Yong. (2018). Financial incentives to encourage value-based health care. Medical care research review, Vol. 75, No. 1, pp. 3-32. https://doi.org/10.1177/1077558716676594 
Simons, R. (1990). The role of management control systems in creating competitive advantage and new perspectives. Accounting, Organizations and Society, Vol. 15, No.1/2, pp. 127-143. https://doi.org/10.1016/0361-3682(90)90018-p

Simons, R. (1995). Levers of Control. How Managers Use Innovative Control Systems to Drive Strategic Renewal. Boston: Harvard Business School Press.

https://doi.org/10.5465/ame.1995.9506273288

Sivertsen, G. (2016). Publication-based funding: The Norwegian model. I Research Assessment in the Humanities: Towards Criteria and Procedures, M. Ochsner, S. E. Hug \& H.-D. Daniel (eds.). Springer.

Smith, P. C. (2007). Formula funding of public services. Oxon: Routledge.

Smith, P. C. (2008). Formula funding of health services: Learning from experience in some developed countries. Discussion paper number 1/2008, World Health Organization, Geneva.

Smith, P. C., N. Rice \& R. Carr-Hill. (2001). Capitation funding in the public sector. Journal of the Royal Statistical Society Series A, Vol. 162, pp. 217-257. https://doi.org/10.1111/1467-985x.00200

Socialdemokratiet (2018). Tillid, faglighed og arbejdsglæde: En selvstyre-reform for den offentlige sektor. Politisk oplæg, foråret 2018.

Sundhedskoordinationsudvalget. (2018). Sundhedsaftale 2015-2018, Region Hovedstaden og kommunerne i regionen. København.

Sundheds- og Aldreministeriet. (2016). Nationale mål for sundhedsvæsenet. Sundheds- og Eldreministeriet, KL og Danske Regioner, april 2016 https://doi.org/10.7146/aul.145.124

Thorball, K. B. (2018). Datadrevne beslutninger og velfærdsanalyse. I Strategi og styring med effekt, P. N. Bukh \& K. S. Christensen (eds.). København: Djøf Forlag.

Undervisningsministeriet. (2014). Indførelse af socialt taxameter og øget geografisk tilskud. Teknisk notat, 6. oktober 2014, Børne- og Undervisningsudvalget 2014-15 BUU. Alm. del endeligt svar på spørgsmål 19.

Van der Stede, W. A. (2001). Measuring 'tight budgetary control'. Management Accounting Research, Vol. 12, No. 1, pp. 119-137. https://doi.org/10.1006/mare.2000.0149

Væksthus for Ledelse. (2009). Ledelsesrum: Udnyt og udvid dine handlemuligheder. Væksthus for Ledelse, maj 2009.

Wolf, A. (2018). Sådan skaber vi et mere værdibaseret sundhedsvæsen. Tidsskrift for Dansk Sundhedsvoesen, Vol. 94, No. 3, pp. 6-11. 
Aarup, K. (2010). Frivillighedens velvoerdssamfund: Er livet et kommunalt anliggende? København: Frydenlund.

\footnotetext{
${ }^{i}$ Tak til Preben Melander samt en anonym reviewer for for meget konstruktive og brugbare kommentarer til en tidligere version af artiklen. Ligeledes vil vi gerne takke Betina Sørensen for hjælp med manuskriptet. Endelig skylder vi en stor tak til flere studerende ved MPG-uddannelsen på Aalborg Universitet for deres mange gode spørgsmål til en tidligere version af artiklen.
}

ii Se f.eks. Boll \& Høeberg (2013), Ejler \& Seiding (2011), Nielsen \& Ejler (2008) samt Hunter \& Nielsen (2013).

iii Mange aktører i sundhedsvæsnet (Danske Regioner 2016; Jensen 2018; Wolf 2018) argumenterer for den danske variant af værdibaseret sundhed, men det er endnu ikke klart, hvordan den fremtidige styring af sundhedsvæsnet kunne se ud, eller hvilke konsekvenser de forskellige bud på ændringer har (Højgaard et al. 2016; Madsen et al. 2017; PWC \& McKinsey 2018). Se desuden Bjerregaard \& Christensen (2018), Bonde et al. (2018), Burau et al. (2018), Jørgensen et al. (2018) samt Mejdahl et al. (2018).

iv Se SBU (2018) for et systematisk litteraturstudie af de internationale erfaringer med VBHC samt Andersson et al. (2019) for en kritisk gennemgang af koncepter og de eksisterende erfaringer hermed.

v Diagnose Relateret Gruppering (DRG) er et klassifikationssystem, der inddeler patienter med samme sygdomme og behandlingsforløb i kategorier. Hver DRG-gruppe tilknyttes en vægt, der angiver det økonomiske ressourcetræk i forhold til andre DRG-grupper. DRG-taksterne opfattes som udgiftsægte priser, der afspejler de faktiske nationale udgifter forbundet med behandlingen (Refnov 2018). Se Srinavasta et al. (2016) for en oversigt over den internationale anvendelse af DRG-systemer såvel som andre former for tildelingsprincipper i sundhedsvæsnet samt fordele og ulemper forbundet med disse.

vi Styringsinstrumenter er: nationale mål, patienttilfredshedsmålinger, produktivitetsopgørelser, specialeplanlægning, kliniske retningslinjer og forløbspakker, frit valg og udvidet frit valg, udbuds- og konkurrencemuligheder, rammestyring (inkl. Budgetloven og sanktioner), puljer, øremærkede/formålsbestemte bevillinger, aktivitetspuljer, produktivitetskrav og kommunal medfinansiering.

vii Undtagelser er dog van der Hengel et al. (2014), der studerer 12 hollandske kommuner og finder, at økonomistyringssystemer ofte er løst koblet mellem de hierarkiske niveauer. Van der Kolk and Schokker (2016) finder i et studie af en enkelt hollandsk kommune, at kommuneplaner og afdelingsplaner er tæt koblet. Endvidere viser Bukh \& Svanholt (2020) , hvordan den hierarkiske kobling af budgetprocesser og teknikker forstærkes, når budgetlægningen er et centralt planlægningsredskab.

viii Skønsmæssige tildelinger kan f.eks. være, at det vurderes, at der er behov for et bestemt antal ledere på en skole, eller at det vurderes, at et hjemmeplejedistrikt har brug for ekstra ressourcer, fordi der er særlig meget kørselstid.

ix Vi bruger her betegnelsen distrikt om den delpopulation eller målgruppe, som tildelingen vedrører. Ofte vil der være tale om skoledistrikter, plejedistrikter, børne- og ungedistrikter eller sundhedsdistrikter, men der kan også være andre former for inddelinger. Det centrale er, at finansieringsansvaret for den enkelte borger kan henføres til ét bestemt distrikt. Se Riise-Knudsen \& Kokholm (2018) for et eksempel.

${ }^{x}$ Se Heinesen \& Kolodziejczyck (2008), Jakobsen (2017), Petersen \& Bæk (2018), Petersen \& Lemvig (2018), Rice \& Smith (2001a, 2001b) samt Smith et al. (2001) for eksempler på anvendelse af statistiske modeller til estimering af et relativt udgiftsbehov i tildelingsmodeller baseret på kapitafinansiering.

xi Bjørnenak (2000) beskriver, hvordan denne form for tildelingsmodel anvendes i Oslo, Bergen, Trondheim og Stavanger til at fastlægge antallet af lærerstillinger på de enkelte skoler. Tildelingsmodellen tager udgangspunkt i en tildeling af undervisningstimer på baggrund af antal klasser og antal elever. Tilsvarende tildeles der ressourcer til ledelsen på baggrund af antal børn i skolerne, mens budgetterne til skolesekretærer, pedeller og rengøring typisk er holdt uden for tildelingsmodellen i disse norske kommuner.

xii Taksten kan antage fire forskellige værdier, idet tre af dem er angivet i tekstboks 1, mens den fjerde har værdien 0 kr., hvis skolen ikke er omfattet af en socioøkonomisk tildeling.

xiii Se også Downes \& Stiefel (2015), der med henvisning til Louis et al. (2003) og Cullen (2003) fremhæver, at der i litteraturen om udligning af serviceforskelle distrikter imellem ('intergovernmental aid') er bred enighed om, at lokalområder ikke skal kompenseres på baggrund af faktorer, der er lokalt påvirkelige. 
${ }^{\text {xiv }}$ Se "Sundhedsminister: Geografisk ulighed i sundhed er en af de største udfordringer". Pressemeddelelse, 7. september 2015, Sundheds- og Aldreministeriet, København.

${ }^{x v}$ Bleyen et al. (2017) sammenligner anvendelsen af resultatbudgettering i europæiske kommuner, mens Mauro et al. (2017) giver en oversigt over litteraturen om resultatbudgettering. Se også Clark et al. (2017), der analyserer spredningen af resultatbudgettering på tværs af OECD-lande.

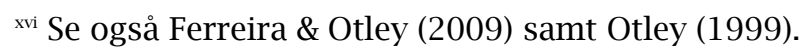

